GUILHERME ANDRADE LUCCI

\title{
A EFETIVAÇÃO DO DIREITO INTERNACIONAL PELA JUSTIÇA BRASILEIRA
}

\author{
Tese de Doutorado \\ Orientador: Prof. Titular Dr. Paulo Borba Casella
}

UNIVERSIDADE DE SÃO PAULO

FACULDADE DE DIREITO

São Paulo - SP

2019 

GUILHERME ANDRADE LUCCI

\section{A EFETIVAÇÃO DO DIREITO INTERNACIONAL PELA JUSTIÇA BRASILEIRA}

Tese apresentada à Banca Examinadora do Programa de Pós-Graduação em Direito, da Faculdade de Direito da Universidade de São Paulo, como exigência parcial para a obtenção do título de Doutor em Direito, na área de concentração de Direito Internacional, sob orientação do Professor Titular Doutor Paulo Borba Casella.

UNIVERSIDADE DE SÃO PAULO

FACULDADE DE DIREITO

São Paulo - SP 
Catalogação da Publicação

Serviço de Biblioteca e Documentação

Faculdade de Direito da Universidade de São Paulo

LUCCI, Guilherme Andrade

A efetivação do direito internacional pela justiça brasileira ; Guilherme Andrade LUCCI ; orientador Paulo Borba CASELLA - - São Paulo, 2019.

$278 \mathrm{p}$.

Tese (Doutorado - Programa de Pós-Graduação em Direito Internacional) - Faculdade de Direito, Universidade de São Paulo, 2019.

1. Direito internacional. 2. Direitos humanos. 3. Efetivação do direito. 4. Poder Judiciário brasileiro. 5. Juiz nacional. I. CASELLA, Paulo Borba, orient. II. Título 


\section{FOLHA DE AVALIAÇÃO}

LUCCI, Guilherme Andrade. A efetivação do direito internacional pela Justiça Brasileira. 2019. 278 p. Tese (Doutorado). Faculdade de Direito, Universidade de São Paulo, São Paulo, 2019.

Avaliado em: $\ldots . / \ldots / \ldots / 20 \ldots$.

\section{Banca Examinadora:}

Prof. Dr. Paulo Borba Casella

Instituição: Universidade de São Paulo

Julgamento:

Prof.(a) Dr.(a)

Instituição:

Julgamento:

Prof.(a) Dr.(a)

Instituição:

Julgamento:

Prof.(a) Dr.(a)

Instituição:

Julgamento:

Prof.(a) Dr.(a)

Instituição:

Julgamento:

Prof.(a) Dr.(a)

Instituição:

Julgamento: 



\section{AGRADECIMENTOS}

Uma jornada assim longa não se dá de forma solitária.

Ao Professor Doutor Paulo Borba Casella, admirável mestre e orientador, que apostou em meu projeto mesmo antes de nos conhecermos pessoalmente. Com seu voto de confiança estimulou-me ainda mais a me esmerar na pesquisa. Sua biografia e sua postura profissional e pessoal se tornaram referências para mim.

Aos Professores da pós-graduação da Faculdade de Direito da Universidade de São Paulo, nas 11 (onze) ricas disciplinas por mim cursadas neste doutorado direito, pelo rigor técnico do ensino oferecido e por me apresentarem suas perspectivas sobre o Direito e sobre o mundo. Em particular, aos Professores Doutores Elizabeth de Almeida Meirelles, Lineide do Lago Salvador Mosca, Masato Ninomiya, Pedro Bohomoletz de Abreu Dallari, Wagner Menezes e Enrique Ricardo Lewandowski, os três primeiros ainda por terem inspirado aprimoramentos neste estudo, durante sua qualificação.

A meus colegas alunos da pós-graduação da Faculdade de Direito de Universidade de São Paulo, pelo convívio acadêmico e pelos frutuosos debates jurídicos. Agradeço-lhes também por terem instigado em mim a habilidade de desenvolver mais e mais a autocontenção diante de críticas, em sala de aula, à atuação do poder judiciário nacional e de seus magistrados, quando pautadas por premissas críticas verdadeiras sob minha perspectiva. Sou-lhes grato, ainda, por terem permitido que eu lhes expusesse defesa ao mesmo poder judiciário e a seus integrantes - profissionais sérios, dedicados, sobrecarregados, estudiosos e conscientes da relevância da atividade estatal que desenvolvem - , quando cabia retificação, sob meu ponto de vista, a alguma premissa que motivara a crítica.

A meus colegas Juízes Federais Danilo Guerreiro de Moraes, Janaina Martins Pontes, Leonardo Pessorrusso de Queiroz, Luciano Tertuliano da Silva e Ricardo Uberto Rodrigues, com quem dividi as venturas e as desventuras da atividade judicante respectivamente em Jaú, Barueri, Campinas, Assis e Campinas. Sua generosidade na 
assunção de designações para o exercício cumulativo da jurisdição foi essencial para que a prestação jurisdicional e os compromissos acadêmicos por mim assumidos fossem sempre bem conciliados, sem prejuízo a nenhum deles.

À equipe que zela pela organização e que promove o enriquecimento do acervo da biblioteca do Tribunal Regional Federal da Terceira Região e das bibliotecas da Justiça Federal desta Seção Judiciária do Estado de São Paulo. Em particular à estimada bibliotecária Elaine de Aquino Cardoso Silva.

Aos jurisdicionados da Justiça Federal da Terceira Região, destinatários finais deste aprimoramento profissional.

À Graziela, ao Felipe, ao William (Júnior) e à Tânia, permanentemente próximos e presentes, mesmo à distância.

A meus queridos pais, Iara e Oswaldo. Os exemplos diários, a fortaleza de amor permanente e as condições emocionais e materiais que sempre ofereceram a mim e a meus irmãos foram essenciais para que seguíssemos adiante, enfrentando os desafios da vida.

À Fernanda, por seu amor e por seu companheirismo nessa jornada e em todas as outras. Também por se desdobrar admiravelmente entre tantos papéis - entre eles, de esposa, de mãe e de Promotora de Justiça -, e ainda assim lhe sobrar tempo, inclusive para programar nossas viagens de férias.

Ao Enrico, por me ensinar, já nestes seus primeiros anos de vida, a multiplicar meu tempo. Muito mais que isso, por me fazer experimentar diariamente a especial infinitude do amor paterno. 
«Comment donc les gens du roi comprennent-ils le mot civilisation?

La civilisation n'est autre chose qu'une série de transformations successives. " Victor Hugo - Le dernier jour d'un condamné 



\section{RESUMO}

LUCCI, Guilherme Andrade. A efetivação do direito internacional pela Justiça brasileira. 2019. 278 p. Tese (Doutorado). Faculdade de Direito, Universidade de São Paulo, São Paulo, 2019.

O direito é instrumento social que deve ser efetivado no plano dos fatos e das relações humanas, razão pela qual deve determinar comportamentos juridicamente relevantes e promover meios à realização da justiça. A característica da instrumentalidade do direito vale, naturalmente, também para o direito internacional. As obrigações jurídicas assumidas pelo estado no plano de suas relações internacionais devem vincular seu comportamento já no plano de suas relações jurídicas nacionais, efetivando-se também nesse âmbito. $\mathrm{O}$ direito internacional deve irradiar efeitos para fora e para dentro das fronteiras do estado que com ele anuiu; deve reger, por meio de suas forças prescritiva e persuasiva, também as relações jurídicas ocorridas em âmbito doméstico. O juiz nacional é agente estatal que deve assumir o protagonismo nessa efetivação do direito internacional. Compete-lhe garantir que o estado atue de maneira coerente nos planos das relações internacionais e das relações nacionais, impedindo que adote posição jurídico-normativa contraditória entre esses âmbitos de atuação. Cabe ao juiz nacional assegurar que de fato se observe a norma jurídica internacional no ambiente das relações nacionais, evitando o descumprimento que implique a responsabilização do respectivo estado perante os organismos internacionais de que seja membro. À justiça brasileira, entendida como o conjunto de órgãos que compõem o poder judiciário nacional brasileiro, compete garantir a consumação, também no âmbito das relações nacionais, da tutela jurídica emanada da norma de direito internacional. Deverá fazê-lo por intermédio da atuação jurisdicional típica e ainda por meio da atuação administrativo-normativa atípica de cada um de seus órgãos. Trata-se de competências que cumprem as obrigações do Estado brasileiro de respeitar a norma internacional e de promover a cooperação entre os estados e as organizações internacionais. Nesse contexto, o compromisso da justiça nacional brasileira com os temas da efetivação da Agenda 2030 das Nações Unidas, da razoável duração dos processos e do cumprimento da Convenção de Haia sobre aspectos do sequestro civil internacional de crianças expressa exemplificativamente seu envolvimento com a efetivação doméstica do direito internacional. A presente tese lança essas premissas para, então, analisar a atuação dos órgãos do poder judiciário brasileiro, dos diversos ramos da estrutura orgânica desse poder, na efetivação do direito internacional, especialmente dos direitos humanos, por intermédio de sua atividade administrativo-normativa e por meio de sua atividade jurisdicional. O estudo estimula a difusão, entre os magistrados nacionais brasileiros, dessa atuação judicial voltada à efetivação, no plano doméstico, dos 
compromissos internacionalmente assumidos pelo Estado brasileiro. Conclui que a efetivação do direito internacional pela justiça brasileira se dá mais firmemente por meio de sua atuação administrativo-normativa - especialmente aquela desenvolvida pelo Conselho Nacional de Justiça, seu órgão administrativo máximo - que por via de sua atividade jurisdicional. Esta última, embora em franco desenvolvimento na invocação do direito internacional, ainda é tímida na invocação da norma internacional como ratio decidendi de seus pronunciamentos e, pois, na efetivação do direito internacional no plano das relações nacionais.

Palavras-chave: Direito internacional. Direitos humanos. Poder Judiciário nacional. Justiça brasileira. Juiz nacional. Efetivação do direito. Eficácia social do direito. 


\begin{abstract}
LUCCI, Guilherme Andrade. The implementation of international law by the Brazilian courts. 2019. 278 p. Thesis (Doctorate). Faculty of Law, University of São Paulo, São Paulo, 2019.
\end{abstract}

Law is a social instrument that must be implemented at the level of facts and human relations, which is why it must determine legally relevant behaviors and promote means for the realization of justice. The characteristic of the instrumentality of law applies, of course, to international law as well. The legal obligations assumed by the State in terms of its international relations must link its behavior already in terms of its national legal relations, also taking effect in this area. International law must radiate effects outside and within the borders of the state that has agreed with it; it must govern, through its prescriptive and persuasive forces, also the juridical relations that occur at the local level. The national judge is a state agent who must take the lead in this implementation. It is responsible for ensuring that the State acts in a coherent manner in terms of international relations and national relations, preventing it from adopting a contradictory legalnormative position between these areas of activity. It is up to the national judge to ensure that the international legal standard is observed in the environment of national relations, avoiding non-compliance that implies the accountability of the State to the international bodies of which it is a member. The Brazilian Justice, understood as the set of organs of the national judiciary, is responsible for ensuring the consummation, also within the scope of national relations, of legal protection emanating from international law. It should do so through the typical jurisdictional action and also through the atypical administrativenormative performance of each of its organs. These are competences that fulfill state obligations to respect the international standard and cooperation between states and international agencies. In this context, for exemple, the commitment of the Brazilian National Justice to the themes of the implementation of the United Nations Agenda 2030, the reasonable duration of the proceedings and compliance with the Hague Convention on aspects of the international civil kidnapping of children expresses its involvement with the domestic implementation of international law. The present thesis sets out these premises to analyze the performance of the organs of the Brazilian judiciary, by the various branches of the organic structure of this power, in the implementation of international law, especially human rights, through its administrative-normative activity and by through its jurisdictional activity. It encourages the diffusion, among national magistrates, of this judicial action aimed at the realization, at the domestic level, of the international commitments assumed by the Brazilian State. It concludes that the implementation of international law by the Brazilian Justice occurs more firmly through its normative 
administrative action - especially that developed by the National Council of Justice, its highest administrative body - than through its jurisdictional activity. This last one, although in rapid development, is still timid in invoking international law as ratio decidendi of its pronouncements and, therefore, in the implementation of international law in terms of national relations.

Keywords: International law. Human rights. National Judiciary. Brazilian justice. National judge. Implementation of international law. Effectiveness of law. 


\section{RÉSUMÉ}

\section{LUCCI, Guilherme Andrade. La mise en ouvre du droit international par la justice}

brésilienne. 2019. 278 p. Thèse (Doctorat). Faculté de droit, Université de Sao Paulo, Sao Paulo, 2019.

Le droit est un instrument social qui doit être mis en œuvre au niveau des faits et des relations humaines. C'est pourquoi il doit déterminer les comportements juridiquement pertinents et promouvoir les moyens de rendre justice. La caractéristique d'être instrument de droit s'applique bien sûr aussi au droit international. Les obligations juridiques assumées par l'État dans ses relations internationales doivent lier son comportement en termes de relations juridiques nationales, prenant également effet dans ce domaine. Le droit international doit émettre des effets dedans e dehors des frontières de l'État qui l'a accepté; il doit régir, par ses forces prescriptives et persuasives, également les relations juridiques qui se développent au niveau local. Le juge national est l'agent de l'État qui doit prendre en charge cette mise en œuvre. Il lui incombe de veiller à ce que l'État agisse de manière cohérente sur le plan des relations internationales et nationales, en l'empêchant d'adopter une position juridico-normative contradictoire entre ces domaines d'activité. Il appartient au magistrat national de veiller au respect de la norme juridique internationale dans l'environnement des relations nationales, en évitant les non-conformités qui impliquent la responsabilité de l'État devant les organisations internationaux dont il est membre. Le pouvoir judiciaire brésilien, par chacun de ses organes, est chargé de veiller, également dans le cadre des relations nationales, d'une protection juridique émanant de la règle du droit international. Il devrait le faire par le biais de la fonction juridictionnelle typique ainsi que de la fonction administrative normative atypique de ses tribunaux. Ce sont des compétences qui remplissent les obligations de l'État de respecter les normes internationales et la coopération internationale entre les États et organisations internationales. Dans ce contexte, par exemple, l'attachement de la justice nationale brésilienne aux thèmes de la mise en œuvre de l'Agenda 2030 des Nations Unies, de la durée raisonnable de la procédure et du respect de la Convention de La Haye sur les aspects des enlèvements internationaux d'enfants exprime son implication dans l'implementation nationale du droit international. Cette thèse pose ces prémisses pour analyser la performance des organes de la justice brésilienne, des différentes branches de sa structure organique, dans la mise en œuvre du droit international, en particulier des droits de l'homme, à travers leur activité normative et administrative et de son activité juridictionnelle. Il encourage la diffusion, parmi les magistrats nationaux, de cette action judiciaire visant à la réalisation, au niveau national, des engagements internationaux souscrits par l'État brésilien. L'étude conclut que la justice brésilienne est plus à même de 
réaliser le droit international par son action administrative normative, en particulier celle développée par le Conseil national de la justice, son principal organe administratif, que par son activité juridictionnelle. Cette dernière, bien que en développement rapide, hésite encore à invoquer la règle du droit international comme la ratio decidendi de ses déclarations et, par conséquent, à mettre en œuvre le droit international en termes de relations nationales.

Mots-clés: Droit international. Droits de l'homme. Judiciaire national. Système judiciaire brésilien. L’implementation de la loi. L'efficacité sociale du droit. 


\section{RIASSUNTO}

\section{LUCCI, Guilherme Andrade. La realizzazione del diritto internazionale da parte dei}

tribunali brasiliani. 2019. 278 p. Tesi di dottorato. Facoltà di Giurisprudenza, Università di São Paulo, São Paulo, 2019.

La legge è uno strumento sociale che deve essere attuato a livello di fatti e relazioni umane, motivo per cui deve determinare comportamenti giuridicamente rilevanti e promuovere mezzi per la realizzazione della giustizia. La caratteristica della strumentalità del diritto si applica, ovviamente, anche al diritto internazionale. Gli obblighi giuridiche assunti dallo Stato in sue relazioni internazionali devono collegare il suo comportamento già in termini di relazioni giuridiche nazionali. Il diritto internazionale deve irradiare effetti al di fuori e all'interno dei confini dello stato; deve governare, attraverso le sue forze prescrittive e persuasive, anche le relazioni giuridiche che si verificano a livello locale. Il giudice nazionale è l'agente statale che deve prendere l'iniziativa in questa implementazione. È responsabile di assicurare che lo Stato agisca in modo coerente nelle relazioni internazionali e nelle relazioni nazionali, impedendogli di adottare una posizione giuridica normativa contraddittoria tra queste aree di attività. Il giudice nazionale deve garantire che lo standard legale internazionale sia rispettato nell'ambiente delle relazioni nazionali, evitando la non conformità e l'attribuzione della responsabilità allo Stato dinanzi agli organismi internazionali di cui è membro. La giustizia brasiliana, intesa come l'insieme degli organi della magistratura nazionale, è responsabile di assicurare la realizzazione, anche nell'ambito delle relazioni nazionali, di una protezione giuridica emanata dal diritto internazionale. Dovrebbe farlo attraverso la tipica azione giurisdizionale e anche attraverso la prestazione atipica amministrativo-normativa di ciascuno dei suoi organi. Si tratta di competenze che soddisfano gli obblighi statali di rispettare lo standard internazionale e di cooperare tra Stati e organizzazioni internazionali. In questo contesto, ad esempio, l'impegno della Giustizia Nazionale brasiliana sui temi dell'attuazione dell'Agenda 2030 delle Nazioni Unite, la ragionevole durata del procedimento e il rispetto ai termini della Convenzione dell'Aia sugli aspetti del rapimento civile internazionale di minori esprime il suo coinvolgimento con l'implementazzione nazionale delle norme di diritto internazionale. Questa tesi definisce queste premesse per, allora, analizzare le prestazioni degli organi della magistratura brasiliana, dei vari rami della sua struttura organica, nell'attuazione del diritto internazionale, in particolare dei diritti umani, attraverso la loro attività amministrativo-normativa e attraverso la sua attività giurisdizionale. Incoraggia la diffusione, tra i magistrati nazionali, di questa azione giudiziaria volta alla realizzazione, a livello nazionale, degli impegni internazionali assunti dallo Stato brasiliano. Conclude che l'attuazione del diritto internazionale da parte 
della giustizia brasiliana avviene più saldamente attraverso la sua azione amministrativa normativa - in particolare quella sviluppata dal Consiglio nazionale di giustizia, il suo più alto organo amministrativo - che attraverso la sua attività giurisdizionale. Questa ultima, sebbene in rapido sviluppo, è ancora timida nell'invocare la norma di diritto internazionale come ratio decidendi dei sui provimenti e, quindi, nell'attuazione del diritto internazionale in termini di relazioni nazionali.

Parole chiave: Diritto internazionale. Diritti umani. Magistratura nazionale brasiliana. Giudice nazionale. La realizzazione del diritto. L'efficacia sociale della legge. 


\section{RESUMEN}

\section{LUCCI, Guilherme Andrade. La aplicación del derecho internacional por la Justicia}

brasileña. 2019. 278 p. Tesis (Doctorado). Facultad de Derecho, Universidad de São Paulo, São Paulo, 2019.

El derecho es un instrumento social que debe implementarse a nivel de los hechos y de las relaciones humanas, por lo que debe determinar comportamientos jurídicamente relevantes y promover medios para la realización de la justicia. La característica de la instrumentalidad del derecho se aplica, por supuesto, también al derecho internacional. Las obligaciones jurídicas asumidas por el Estado en términos de sus relaciones internacionales deben vincular su comportamiento ya en términos de sus relaciones jurídicas nacionales. El derecho internacional debe irradiar efectos afuera y adentro de las fronteras del Estado que lo ha acordado; debe gobernar, a través de sus fuerzas prescriptivas y persuasivas, también las relaciones jurídicas que se producen a nivel local. El juez nacional es un agente estatal que debe tomar la iniciativa en esta implementación. Es responsable por garantizar que el Estado actúe de manera coherente en términos de relaciones internacionales y de relaciones nacionales, evitando que adopte una posición jurídico-normativa contradictoria entre estas áreas de actividad. Corresponde al juez nacional garantizar que se cumpla el estándar jurídico internacional en las relaciones nacionales, evitando el incumplimiento que implica la responsabilidad del Estado ante los organismos internacionales de los que es miembro. La justicia brasileña, entendida como el conjunto de órganos del poder judicial nacional, es responsable por garantizar la consumación, también a lo alcance de las relaciones nacionales, de la protección jurídica que emana del estado de derecho internacional. Debe hacerlo a través de la acción jurisdiccional típica y también a través del desempeño atípico administrativo-normativo de cada uno de sus órganos. Estas son competencias que cumplen con las obligaciones estatales de respetar el estándar internacional y la cooperación entre estados y organismos internacionales. En este contexto, el compromiso de la Justicia brasileña con los temas de la implementación de la Agenda 2030 de las Naciones Unidas, la duración razonable de los procedimientos y el cumplimiento de la Convención de La Haya sobre aspectos del secuestro civil internacional de niños expresa, como ejemplos, su participación en la realización nacional del derecho internacional. La presente tesis establece estas premisas para entonces analizar las acciones de los órganos del poder judicial brasileño, de las diversas ramas de la estructura orgánica de este poder, en la implementación del derecho internacional, especialmente de los derechos humanos, a través de su actividad administrativa-normativa y a través de su actividad jurisdiccional. Fomenta la difusión, entre los magistrados nacionales, de esta acción judicial dirigida a la realización, a nivel 
interno, de los compromisos internacionales asumidos por el Estado brasileño. Concluye que la implementación del derecho internacional por parte de la Justicia brasileña ocurre más firmemente a través de su acción administrativa normativa, especialmente la desarrollada por el Consejo Nacional de Justicia, su máximo órgano administrativo, que a través de su actividad jurisdiccional. Esta última, aunque en rápido desarrollo, todavía es tímida al invocar la norma de derecho internacional como ratio decidendi de sus pronunciamientos y, por lo tanto, en la implementación del derecho internacional en términos de relaciones nacionales.

Palabras clave: Derecho internacional. Derechos humanos. Poder judicial nacional. Justicia brasileña. Juez nacional. Efectividad de la ley. Eficacia social del derecho. 


\section{SUMÁRIO}

\section{CAPÍTULO 1 : DIREITO INTERNACIONAL NA BALANÇA DA JUSTIÇA}

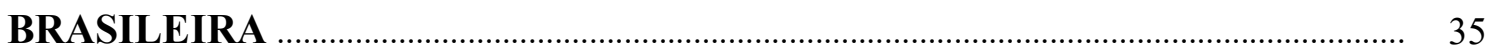

1.1 Poder Judiciário brasileiro e direito internacional …………………............................. $\quad 35$

1.1.1 Justiça brasileira genérica e especificamente considerada ............................................. 35

1.1.2 Protagonismo judicial no plano doméstico ………..................................................... 42

1.2 Efetivação do direito internacional no âmbito nacional ................................................. 49

1.2.1 Eficácia social do direito internacional no plano doméstico .......................................... 49

1.2.2 Confluência jurídico-normativa material com o direito nacional .................................. 56

1.2.3 Efetivação do direito internacional e seu resultado prático local .................................... 63

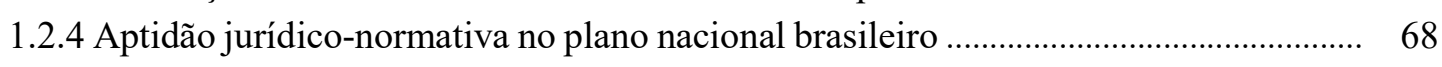

1.2.5 Comportamento estatal contraditório violador do direito internacional ....................... $\quad 77$

1.3 Atenção da justiça brasileira ao direito internacional ……………………................... 82

1.3.1 Direito internacional efetivado pelo magistrado nacional .......................................... 82

1.3.2 Comedimento do juiz brasileiro na aplicação do direito internacional ........................ 87

1.3.3 Compromisso com a efetivação do direito internacional .............................................. 93

\section{CAPÍTULO 2: ALGUMAS INTERAÇÕES DA JUSTIÇA BRASILEIRA}

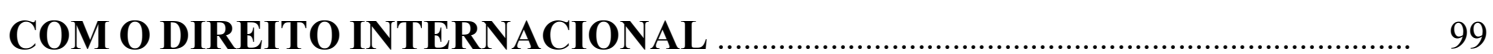

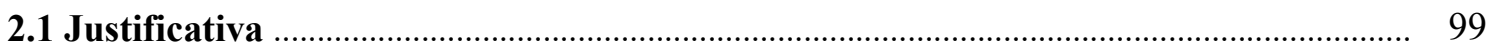

2.2 Especial deferência aos direitos humanos ...................................................................... 100

2.2.1 Jurisdição nacional e direitos humanos .......................................................................... 100

2.2.2 Efeito mais imediato do sistema interamericano sobre a jurisdição nacional ............... 103

2.2.3 Cooperação da justiça nacional à efetividade dos direitos humanos ............................. 106

2.3 Direito ambiental : a Agenda 2030 para o desenvolvimento sustentável e a atuação

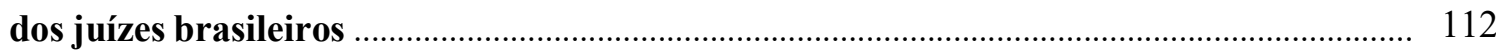

2.3.1 Agenda 2030 e sua necessária observância ..................................................................... 112

2.3.2 Atuação dos juízes nacionais contra a tragédia dos bens comuns .................................. 115

2.3.3 Agenda 2030, juiz nacional e crise ambiental: sobre o cuidado com a casa

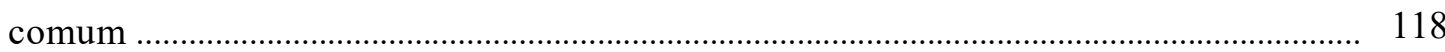

2.3.4 Cumprimento da Agenda 2030 pelos poderes judiciários domésticos ......................... 121

2.4 Acesso à justiça e razoável duração do processo ............................................................... 125

2.4.1 Considerações preliminares ..................................................................................... 125

2.4.2 Profusão normativa do direito à razoável duração do processo ................................... 128

2.4.3 Divergência quanto a seus critérios definidores ............................................................. 131

2.4.4 Indevida modulação do tempo razoável do processo segundo a atual defasagem estrutural dos órgãos da justiça brasileira ............................................................................. 138

2.4.5 Considerações conclusivas sobre a razoável duração do processo e sua efetivação pela justiça brasileira ..................................................................................................... 140 
2.5 Efetivação pela justiça federal brasileira da Convenção de Haia sobre sequestro internacional de crianças e adolescentes

2.5.1 Competência da justiça federal brasileira sobre a matéria ............................................... 143

2.5.2 Convenção de Haia de 1980 e atuação da justiça nacional ............................................ 146

2.5.3 Conflito entre a celeridade e a segurança no cumprimento da Convenção ................... 148

2.5.4 Conflitos entre as justiças estadual e federal na efetivação da Convenção ................... 154

\section{CAPÍTULO 3 : FUNÇÃO ATÍPICA DA JUSTIÇA BRASILEIRA E} EFETIVAÇÃO DO DIREITO INTERNACIONAL

3.1 Atividades atípicas do poder judiciário brasileiro ………………………….................. 157

3.2 Conselho Nacional de Justiça : ampla efetivação dos direitos internacionais ................ 161

3.2.1 Considerações gerais .......................................................................................... 161

3.2.2 Igualdade de gênero dentro e fora da estrutura do poder judiciário brasileiro ............... 168

3.2.3 Proteção da criança e do adolescente ............................................................................ 178

3.2.4 Direitos da população privada de liberdade pelo Estado ......................................... 186

3.2.5 Outros temas igualmente relevantes ................................................................................ 194

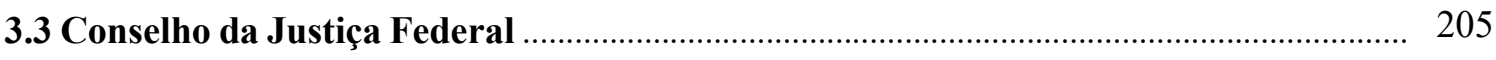

3.4 Conselho Superior da Justiça do Trabalho ...................................................................... 208

3.5 Demais órgãos do poder judiciário brasileiro …........................................................ 210

\section{CAPÍTULO 4 : JURISDIÇÃO BRASILEIRA E EFETIVAÇÃO DO DIREITO} INTERNACIONAL .................................................................................................. 213

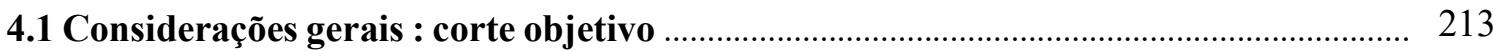

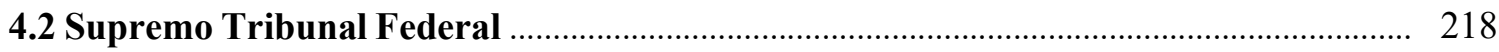

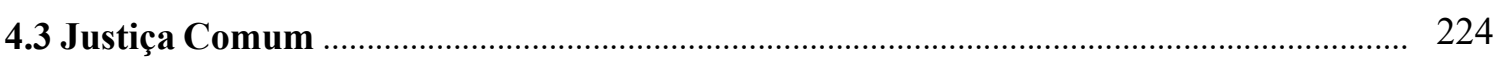

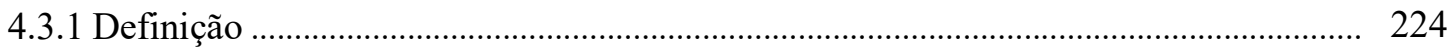

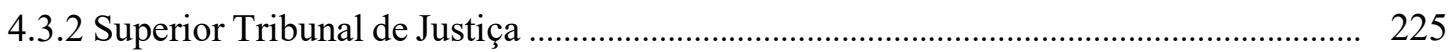

4.3.3 Justiça Federal ........................................................................................................... 227

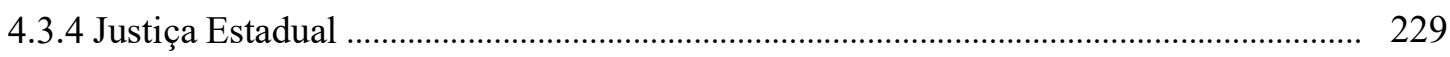

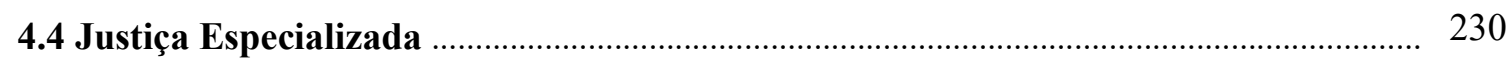

4.4.1 Justiça do Trabalho ................................................................................................... 230

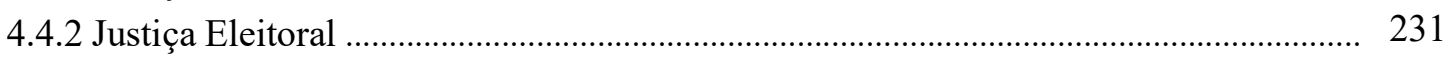

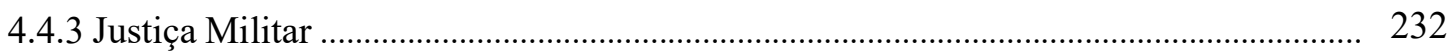

CONCLUSÃO

REFERÊNCIAS BIBLIOGRÁFICAS _......................................................................... 245

Bases doutrinárias em meio físico ..................................................................................... 245

Bases doutrinárias em meio eletrônico .................................................................................. 251

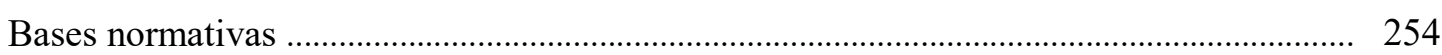

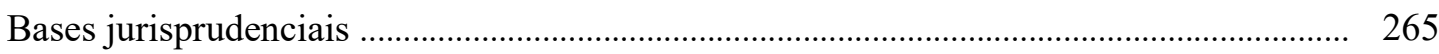

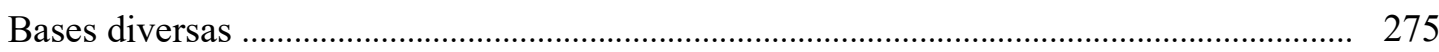




\section{INTRODUÇÃO}

O juiz de instrução observou-o com curiosidade e de pronto quis dele saber se já constituíra advogado. Mersault, então, respondeu negativamente ao magistrado e em seguida lhe questionou se a providência era realmente necessária, já que ele próprio considerava singelo o processo criminal de que se tornara réu. O juiz, então, asseveroulhe que era medida processual imprescindível, segundo as normas jurídicas observadas pelo Estado francês. Por tal razão, diante da negativa de constituição voluntária, o magistrado lhe afirmou que o Estado lhe garantiria a nomeação de um advogado, que lhe exerceria a defesa técnica naquele processo criminal. ${ }^{1}$

Em verdade, cumpria ao advogado nomeado a Mersault a improvável missão de movê-lo de sua própria misantropia e de sua indiferença em relação à vida e à humanidade, desapreço que a continuidade da Segunda Guerra Mundial também expressava ao tempo em que o autor, Albert CAMUS, escrevia $O$ Estrangeiro. Assim, ao lançar sua obra, em 1942, ainda no curso daquela Guerra, às vésperas de os direitos humanos passarem a ocupar posição jurídica de destaque no direito e no cenário internacionais, CAMUS registra a importância de esses direitos irradiarem efeitos concretos e imediatos no mundo dos fatos. Ainda, indica a relevância de que tais efeitos sejam efetivamente experimentados também no âmbito das relações jurídicas havidas no plano das relações nacionais, por intermédio da atividade do poder judiciário nacional, sobretudo contra a atuação do próprio estado. ${ }^{2}$ Com isso, anota, ainda, o relevante papel juridicamente

\footnotetext{
${ }^{1}$ CAMUS, Albert. O Estrangeiro, 1. ${ }^{\text {a }}$ ed. Antônio Quadros (tradutor). São Paulo: Abril Cultural, 1972, pp. 83 e 84.

${ }^{2}$ Nota deste autor: nesse caso, o magistrado nacional garantiu a efetivação, ao menos no inicial momento daquele processo criminal, do direito ao devido processo legal, já então registrado, entre outros, no artigo 7. ${ }^{\circ}$ da Declaração de Direitos do Homem e do Cidadão (1789): “Art. $7^{\circ}$. Ninguém pode ser acusado, preso ou detido senão nos casos determinados pela lei e de acordo com as formas por esta prescritas. Os que solicitam, expedem, executam ou mandam executar ordens arbitrárias devem ser punidos; mas qualquer cidadão convocado ou detido em virtude da lei deve obedecer imediatamente, caso contrário torna-se culpado de resistência.”. Declaração disponível em http://www.direitoshumanos.usp.br/index.php/Documentos-anteriores-\%C3\%A0cria $\%$ C3\%A7\%C3\%A3o-da-Sociedade-das-Na\%C3\%A7\%C3\%B5es-at\%C3\%A9-1919/declaracao-dedireitos-do-homem-e-do-cidadao-1789.html. Acesso em: 30 mai. 2019.
} 
possível ao sistema nacional de justiça no desenvolvimento dessa atividade de efetivação de direitos internacionais, especialmente dos direitos humanos, no plano doméstico. Expressa que essa atividade pode ser desenvolvida por meio da efetiva aplicação desses direitos em cada caso concreto submetido ao julgamento do poder judiciário nacional e por meio da concreta perspectiva de que a norma jurídica internacional pode de fato irradiar, também no plano das relações nacionais, os efeitos que motivam sua edição.

Deveras, é essencialmente por meio das instituições administrativas e judiciárias oficiais de cada um dos estados que se dá a realização do direito internacional, especialmente dos direitos humanos. ${ }^{3}$

A norma de direito internacional difunde efeitos jurídicos também no plano das relações jurídicas nacionais. A efetividade dessa norma no plano doméstico está, em boa medida, diretamente relacionada com o comprometimento dos órgãos do poder judiciário nacional. Cabe-lhes, nos processos jurisdicionais que lhe são apresentados a julgamento e na atividade de administração da justiça, observar-lhes a juridicidade e lhes impor a observância aos jurisdicionados, sobretudo aos entes, entidades, órgãos e agentes que integram a própria estrutura oficial do estado.

De fato, os direitos internacionais também se realizam substancialmente dentro das fronteiras de cada estado. ${ }^{4}$ A efetivação do direito internacional vigente, particularmente

\footnotetext{
${ }^{3}$ Cf. CASELLA, Paulo Borba. Fundamentos do Direito Internacional Pós-Moderno. São Paulo: Quartier Latin, 2008. p. 1268: "as questões ligadas à jurisdição e à competência do estado têm de ser vistas, e entendidas, têm de ser conceitualmente situadas, à luz da jurisdição e competências do estado, na aplicação do direito internacional. Não como fins em si mesmas, mas como expressão e mecanismo de operação do direito internacional existente. E que pode preparar o caminho para direito internacional que vá mais adiante, de modo a abranger a 'sociedade internacional', como todo, na condição de sujeito internacional pósmoderno".

${ }^{4}$ Já o preâmbulo e o artigo 22 da Declaração Universal dos Direitos Humanos registram a importância da adoção de medidas de ordem nacional no seu reconhecimento e na sua efetivação: "Preâmbulo: A Assembleia Geral proclama a presente Declaração Universal dos Direitos Humanos como ideal comum a atingir por todos os povos e todas as nações, a fim de que todos os indivíduos e todos os órgãos da sociedade, tendo-a constantemente no espírito, se esforcem, pelo ensino e pela educação, por desenvolver o respeito desses direitos e liberdades e por promover, por medidas progressivas de ordem nacional e internacional, o seu reconhecimento e a sua aplicação universais e efectivos tanto entre as populações dos próprios Estados membros como entre as dos territórios colocados sob a sua jurisdição." Artigo 22: "Toda a pessoa, como membro da sociedade, tem direito à segurança social; e pode legitimamente exigir a satisfação dos direitos econômicos, sociais e culturais indispensáveis, graças ao esforço nacional e à cooperação internacional, de harmonia com a organização e os recursos de cada país". Disponível em https://www.ohchr.org/EN/UDHR/Documents/UDHR_Translations/por.pdf. Acesso em: 10 fev. 2018.
} 
dos compromissos internacionalmente assumidos, sobretudo daqueles relacionados com o respeito aos direitos humanos, depende, em larga escala, portanto, do envolvimento institucional de cada órgão do estado no plano de suas atuações e de suas relações jurídicas domésticas.

Os órgãos que constituem o sistema nacional de justiça - poder judiciário, ministério público, defensoria pública e advocacia pública e privada - têm particular responsabilidade na realização dessa tarefa de garantir efetividade ao direito internacional no plano nacional.

O estado, por essa estrutura, especialmente pela atuação de seu poder judiciário nacional, deve dirigir preocupação pragmática com a efetividade do direito internacional no plano nacional. Cabe-lhe aplicar, em sua atuação regulatória atípica e em sua atividade jurisdicional típica, os valores jurídicos internacionalmente consagrados e as normas celebradas e admitidas, mais ainda quando relacionadas à proteção dos direitos humanos. Cabe-lhe torná-los tangíveis ao mundo dos fatos experimentados no contexto das relações ordinárias da vida que flui dentro do território nacional.

Não só às normas nacionais se deve atribuir máxima efetivação, pois. Também as normas jurídicas emanadas do direito internacional devem servir à transformação da realidade social local, de modo a que elas tangenciem o mundo do ser, regrando-o ao modo do dever-ser jurídico. Seu efeito operativo deve ser sentido no âmbito das relações internacionais como no plano das relações jurídicas nacionais. Não há sentido jurídico ou social em o direito internacional obrigar o estado apenas em suas relações internacionais. Não está o estado autorizado a ignorar o direito internacional na ambiência de suas próprias relações domésticas, na interação com os seus administrados e jurisdicionados, sonegando a estes a aplicação de valores e de normas jurídicas oferecidos à regência das relações internacionais desse mesmo estado.

O poder judiciário nacional, por cada um de seus órgãos, é ator institucionalizado. ${ }^{5}$ Exerce autoridade estatal e impõe a observância, nos processos jurisdicionais que lhe são apresentados a julgamento e em sua atuação atípica normativa,

${ }^{5}$ FERRAZ JR., Tércio Sampaio. Introdução ao Estudo do Direito. 6 a ed.. São Paulo: Atlas, 2011. Capítulo 4, item 4.1. p. 68. 
da autoridade da norma jurídica. Os magistrados nacionais, pois, são agentes encarregados de declarar a normatividade das regras jurídicas, de estabelecer normas procedimentais necessárias a seu próprio funcionamento e de dizer o direito aplicável aos casos concretos entregues a seu julgamento.

É ao juiz nacional, especialmente aos de grau ordinário de jurisdição, que a notícia acerca da violação ou da iminência de violação de um direito essencial, com o correspondente pedido de tutela, chegam mais prontamente. É a ele, portanto, que se impõe, após provocado pelos demais órgãos do sistema de justiça, atuar mais rapidamente na preservação e no restabelecimento da eficácia desses direitos.

Deverá fazê-lo atento aos marcos normativos do direito nacional, sem dúvida. Todavia, deverá fazê-lo também atento aos marcos oferecidos pelo direito internacional. Caber-lhe-á adotar os valiosos parâmetros normativos e hermenêuticos (res interpretata) ${ }^{6}$ fixados por este ramo do direito e pelos órgãos integrantes dos sistemas de proteção dos direitos internacionais, sobretudo dos direitos humanos.

Por certo há um elevado número de valores e princípios de direito internacional que se relacionam e mesmo se confundem com aqueles consagrados no próprio estatuto do estado e nas suas leis internas. Essa fusão material não nega a aplicação do direito internacional sob o discurso da efetividade exclusiva da norma interna. Antes, viabiliza-a no plano interno. O direito internacional muitas vezes se aplica materialmente, embora indiretamente, por intermédio da aplicação do direito positivo interno, ao se valer dos valores e mesmo das normas jurídicas positivas vigentes no próprio ordenamento jurídico nacional. Em via de mão-dupla, a norma de direito nacional não raras vezes é criada a partir de determinante inspiração oferecida pelas normas de direito internacional. Mais que isso, é o teor do direito internacional que acaba por dar amparo material à própria validade jurídica do direito interno ${ }^{7}$, atribuindo-lhe legitimidade e relevância jurídicas,

\footnotetext{
6 Sobre a vinculação indireta 'erga omnes' aos Estados parte da Convenção Americana de Direitos Humanos, ver voto arrazoado do Juiz Eduardo Ferrer Mac-Gregor Poisot na Resolução de 20 de março de 2013 da Corte Interamericana de Direitos Humanos, caso Gelman vs. Uruguai, supervisão de cumprimento de sentença, parágrafo 43 e seguintes.

${ }^{7}$ Nesse sentido, e.g., a Lei federal ${ }^{\circ} 13.146$, de 6 de julho de 2015, que institui o Estatuto da Pessoa com Deficiência. A lei foi inspirada determinantemente na Convenção Internacional sobre os Direitos das Pessoas com Deficiência e em seu protocolo facultativo, assinados em Nova York há mais de 8 anos, em 30 de março de 2007. A Convenção foi aprovada pelo Congresso Nacional por meio do Decreto Legislativo $\mathrm{n}^{\circ}$
} 
dos quais o direito nacional não gozaria sem o correspondente amparo material da norma de direito internacional.

Nesse contexto, é relevante a atividade que as cortes nacionais de justiça podem verdadeiramente desenvolver. Podem dar efetivação ao direito internacional, aplicando-o como instrumento de contenção da atuação dos demais mecanismos oficiais do estado. Podem ainda assegurar elevado grau de normatividade e de efetividade dos direitos internacionais no plano das relações nacionais. ${ }^{8}$

No plano da realidade institucional brasileira, a tal papel jurisdicional, somam-se as atribuições atípicas normativa e administrativa exercidas pelos órgãos do poder judiciário nacional, sobretudo pelo Conselho Nacional de Justiça. Há que se evidenciar que a atuação atípica dos órgãos do poder judiciário nacional, sobretudo sua atuação normativa, expressa valioso instrumento institucional de efetivação do direito internacional no plano doméstico. Essa atividade é vocacionada a estabelecer normatização cuja observância é obrigatória aos demais órgãos judiciários brasileiros, à exceção do Supremo Tribunal Federal. Portanto, trata-se de atividade que rege abstratamente a atuação jurisdicional do Estado-juiz brasileiro.

O presente estudo analisa as possibilidades concretas, os limites e o estágio atual de aplicação do direito internacional no plano nacional brasileiro por intermédio da atuação do sistema brasileiro de justiça. Avalia o quanto a função típica (jurisdicional) e a função atípica (normativa e administrativa) desenvolvidas pelos órgãos do poder judiciário nacional participam ou podem participar ativamente da máxima aplicação e da plena efetivação, em âmbito doméstico, das normas do direito internacional, especialmente dos direitos humanos.

186, de 9 de julho de 2008, e promulgada pelo Presidente da República em 25 de agosto de 2009, por intermédio do Decreto $\mathrm{n}^{\circ}$ 6.949. Em 09 de junho de 2016, o Supremo Tribunal Federal, no julgamento da ação direta de inconstitucionalidade $\mathrm{n}^{\circ} 5357 / \mathrm{DF}$, declarou constitucionais as normas então contestadas da Lei $n^{\circ}$ 13.146. A Corte invocou como razão de decidir, inter alia, os valores consagrados na Convenção.

${ }^{8}$ Cf. IWASAWA, Yuji. Domestic application of International law. RCADI, 378 Recueil des cours 92015. p. 19-261. A propósito dessa função das cortes domésticas, refere (p. 243): "The primary function of domestic courts is to enforce international law against their own Government and assure that their Government does not violate international law. In consequence, the more active and vigorous domestic courts are, the more likely States are to comply with international law". 
O presente estudo observa que os juízes nacionais devem reconsiderar sua habitual autocontenção na invocação do direito internacional como razão de decidir de seus provimentos jurisdicionais. Devem fazê-lo também em relação à sua atuação normativa na regulação de procedimentos. Na revisão de atos estatais ou particulares que violem as normas materiais do direito internacional, devem invocá-las expressamente, em favor de torná-las mais efetivas no plano interno. Essa atividade não é apenas facultada ao juiz brasileiro; é-lhe compulsória ${ }^{9}$. A inobservância do direito internacional pelo magistrado nacional remeterá o Estado brasileiro à condição de agente violador dos tratados de que é parte e que lhe impõem essa observância. ${ }^{10}$

Realmente, o desrespeito omissivo ou comissivo, pelo estado, de normas de direito internacional é comportamento que desperta a possibilidade de sua responsabilização internacional, com risco de imposição de sanções correspondentes pelos sistemas internacionais de proteção de direitos. Esses sistemas, suprindo inação estatal prévia, têm chamado o estado, que atua pelos órgãos autônomos relacionados a seus 'três poderes', à responsabilidade para que atue conforme o direito internacional também no plano doméstico.

Pretende-se com a presente tese, nessa ordem de ideias, expor a base doutrinária e normativa a que as normas de direito internacional possam determinar de forma mais nítida, direta, pragmática e finalística a atuação pública dos entes, entidades, órgãos e agentes estatais no plano interno brasileiro. Essa atuação, enfim, pode ser juridicamente estimulada a partir de previsões normativas e de cominações jurisdicionais, decorrentes respectivamente da atuação atípica e típica de cada um dos órgãos do poder judiciário brasileiro.

\footnotetext{
${ }^{9} \mathrm{O}$ artigo $1^{\circ}$ da Convenção Americana sobre Direitos Humanos prevê: "Os Estados Partes nesta Convenção comprometem-se a respeitar os direitos e liberdades nela reconhecidos e a garantir seu livre e pleno exercício a toda pessoa que esteja sujeita à sua jurisdição (...)". Disponível em https://www.cidh.oas.org/basicos/portugues/c.convencao_americana.htm. Acesso em: 10 fev. 2018.

${ }^{10}$ Ver a respeito, e.g., CORTE INTERAMERICANA DE DIREITOS HUMANOS. Caso Herzog e outros vs. Brasil. Exceções Preliminares, Mérito, Reparações e Custas. Sentença de 15 de março de 2018. Série C, $\mathrm{n}^{\circ}$ 353. Disponível em http://www.corteidh.or.cr/docs/casos/articulos/seriec_353_por.pdf. Acesso em 26 mar. 2019.
} 
Diversamente do que se nota no âmbito das relações jurídicas internacionais, no âmbito das relações e das lides havidas no ambiente doméstico, o poder judiciário nacional é protagonista da efetividade do direito internacional. Neste espaço lhe cabe desenvolver relevante papel em prol da promoção e da realização das normas emanadas do direito internacional. A ele compete impor às partes e a terceiros, inclusive aos próprios entes federados e às entidades do estado, assim também às empresas transnacionais, a observância dessas normas nos casos que lhe são submetidos a julgamento.

O direito internacional, portanto, pode alcançar outro patamar de efetividade formal e material no plano das relações jurídicas e sociais havidas na realidade da vida nacional brasileira. Para isso, é relevante a aplicação de seus valores e de suas normas também no plano das relações jurídicas domésticas. Esse objetivo se realiza mediante a incidência, no plano nacional, do regramento jurídico-normativo internacional ou mesmo do regramento jurídico-normativo nacional materialmente naquele inspirado. Esse objetivo também é alcançado mediante a atuação atípica regulatória dos órgãos administrativos do poder judiciário brasileiro, quando preocupada com a realização de normas e de valores estimados pelo direito internacional, sobretudo aqueles relacionados à tutela dos direitos humanos.

Assim, temas referidos aos direitos do acesso à justiça, aos direitos das crianças e dos adolescentes, aos direitos das mulheres e da igualdade de gênero, aos direitos dos portadores de necessidades especiais, ao direito ao meio ambiente equilibrado, aos direitos da população privada de liberdade pelo Estado, aos direitos dos povos indígenas, aos direitos relacionados à identidade de gênero e à orientação sexual, aos direitos dos refugiados e dos migrantes, aos direitos dos idosos, entre outros, que recebem amplo tratamento do direito internacional, são caros também ao poder judiciário nacional e dele devem provocar atuação em prol de sua efetividade. Também valiosos à justiça nacional são outros temas versados pelo direito internacional com forte interação na realidade doméstica, não propriamente relacionados aos direitos humanos, como os direitos previstos em tratados sobre matéria tributária, sobre direito do consumidor, sobre os direitos que regulam a aviação comercial civil e empresarial, sobre os direitos das telecomunicações, entre tantos outros. 
Nesse contexto, interessa ao presente estudo, como exemplo de aproximação entre os interesses tutelados pela norma de direito internacional e aqueles tutelados pela norma de direito interno, a análise do princípio da razoável duração do processo, como expressão do direito de acesso efetivo à justiça. Afeta o tema a comparação entre os tratamentos jurídicos que a ele lhe dão a Corte Interamericana de Direitos Humanos, a Corte Europeia de Direitos Humanos e o Supremo Tribunal Federal, com as peculiaridades que cada uma dessas cortes confere ao princípio.

Interessa ainda analisar o relevante papel que a jurisprudência emanada das cortes internacionais, a quem cumpre originariamente interpretar e aplicar o direito internacional, desenvolve perante as cortes nacionais. É importante, nessa interação, o registro da irradiação de efeitos ao menos persuasivos sobre o alcance e sobre a interpretação de normas jurídicas internacionais. Seu objeto material - ou seja: o bem jurídico tutelado pela norma -, sobretudo quando referido a direitos humanos, relaciona-se profundamente com o objeto contemplado pelas normas nacionais, especialmente aquelas que tratam dos direitos fundamentais.

O presente estudo declina atenção à obrigação de mútua cooperação do Estado brasileiro, membro que é da comunidade internacional, por intermédio e da participação efetiva de todos os seus agentes, especialmente dos seus juízes nacionais, na efetivação do direito internacional. Sob essa perspectiva, emerge a preocupação com o atingimento de metas ambientais de interesse comum a todos os povos e com a efetivação do direito internacional relacionado ao valor ambiental. Entre essas metas, revela-se interessante a este estudo a análise da interação da Agenda 2030 das Nações Unidas para o desenvolvimento sustentável e o papel, entregue aos magistrados nacionais brasileiros, dirigido à sua implementação. Esses atores, na execução de suas competências, devem-se envolver e se comprometer, por meio de todos os instrumentos oficiais a seu alcance, para que se evite a tragédia dos bens comuns.

Outros temas que diretamente condizem com a atuação da jurisdição nacional na efetivação do direito internacional merecem atenção neste estudo, entre os quais o tema do sequestro civil internacional de crianças e adolescentes de até 16 anos de idade. São relevantes os efeitos normativos da Convenção respectiva (Convenção sobre os aspectos 
civis do sequestro internacional de crianças, de $1980^{11}$ ), promulgada pelo Decreto $\mathrm{n}^{\circ}$ $3.413 / 2000{ }^{12}$, na ordem jurídica nacional e na atuação do juiz federal brasileiro, autoridade judiciária competente para o processamento e o julgamento de casos envolvendo esse objeto.

Igualmente importante ao presente estudo e emblemático do objeto da presente tese se apresenta o papel normativo desenvolvido pelo Conselho Nacional de Justiça e pelos demais órgãos integrantes do poder judiciário brasileiro na efetivação do direito internacional. Normas jurídicas, gerais e abstratas, emanadas desses órgãos e dirigidas ao sistema de justiça e ao funcionamento da própria prestação jurisdicional, são valiosos meios de que se vale o poder judiciário brasileiro na efetivação do direito internacional no plano das relações jurídicas nacionais.

Exemplo mais claro dessa percepção é a edição, pelo Conselho Nacional de Justiça, da Resolução $n^{\circ} 289^{13}$, de 14 de agosto de 2019, que dispõe sobre o sistema nacional de adoção. Em seu preâmbulo, expressamente considera as normas referentes ao instituto do acolhimento e da adoção, versadas na legislação nacional e nos acordos ou pactos internacionais de que o Brasil seja signatário. A edição da Resolução e o controle administrativo de sua observância pelos demais órgãos do poder judiciário brasileiro demonstram o comprometimento desses órgãos de justiça com a efetivação das normas de direito internacional pertinentes ao tema.

Também expressiva desse papel normativo é a edição da Resolução $n^{\circ} 213$, de 15 de dezembro de $2015^{14}$. Por meio dele, o Conselho Nacional de Justiça instituiu, para

\footnotetext{
${ }^{11}$ NAÇÕES UNIDAS. Convenção sobre os aspectos civis do sequestro internacional de crianças, de 25 de outubro de 1980. Disponível em https://assets.hcch.net/docs/bbca6301-9847-470b-ac474635cb1e7cbd.pdf. Acesso em: 10 mar. 2019.

12 BRASIL. Decreto n 3.413, de 14 de abril de 2000. Promulga a Convenção sobre os Aspectos Civis do Sequestro Internacional de Crianças, concluída na cidade de Haia, em 25 de outubro de 1980. Disponível em http://www.planalto.gov.br/ccivil_03/decreto/D3413.htm. Acesso em: 10 mar. 2019.

${ }^{13}$ CONSELHO NACIONAL DE JUSTIÇA. Resolução no 289, de 14 de agosto de 2019. Dispõe sobre a implantação e funcionamento do Sistema Nacional de Adoção e Acolhimento - SNA e dá outras providências. $\quad$ Disponível em http://www.cnj.jus.br/images/atos_normativos/resolucao/resolucao_289_14082019_15082019141539.pdf. Acesso em: 19 ago. 2019.

${ }^{14}$ Idem. Resolução n ${ }^{\circ} 213$, de 15 de dezembro de 2015. Dispõe sobre a apresentação de toda pessoa presa à $\begin{array}{lllllll}\text { autoridade judicial no } & \text { prazo } & \text { de } & 24 & \text { horas. } & \text { Disponível } & \mathrm{em}\end{array}$
} 
todos os órgãos do poder judiciário brasileiro, à exceção do Supremo Tribunal Federal, a obrigatoriedade de que eles, no exercício de suas respectivas competências, exijam a apresentação, ao magistrado competente, no prazo de 24 horas, de toda pessoa presa, para a realização da audiência de apresentação, também denominada de audiência de custódia. Dispositivos de três instrumentos jurídicos do direito internacional fundamentaram direta e expressamente a edição desse ato normativo: o artigo $9^{\circ}$, item 3 , do Pacto internacional de direitos civis e políticos das Nações Unidas ${ }^{15}$, o artigo 2.1 da Convenção contra a tortura e outros tratamentos ou penas cruéis, desumanos ou degradantes das Nações Unidas ${ }^{16}$ e ainda o artigo $7^{\circ}$, item 5 , da Convenção americana sobre direitos humanos da Organização dos Estados Americanos. ${ }^{17}$

Por fim, interessa ao presente estudo o comprometimento da jurisdição brasileira com a efetivação do direito internacional, mediante a aplicação de seus valores e de suas normas pelas cortes nacionais de justiça. Alguns julgados de cada um dos segmentos orgânicos do poder judiciário brasileiro foram selecionados para, à guisa de exemplo, demonstrar criticamente a efetivação do direito internacional por intermédio da jurisdição nacional. A citação dos precedentes jurisprudenciais indicados visa a demonstrar que de fato é possível dar efetividade às normas de direito internacional no plano interno, cumprindo o poder judiciário brasileiro o papel de realização dessas normas jurídicas e de promoção do direito internacional no âmbito doméstico.

Enfim, a atividade judicial nacional atenta ao direito internacional expressa verdadeira atividade de diplomacia judiciária. Assim o será a atividade cooperativa internacional desenvolvida pelo poder judiciário brasileiro. A justiça brasileira desse modo atua quando de fato coloca em operação eficaz, no plano das relações jurídicas

https://www.cnj.jus.br/images/atos_normativos/resolucao/resolucao_213_15122015_23112018141721.pdf Acesso em: 10 mar. 2019.

15 NAÇÕES UNIDAS. Pacto Internacional de Direitos Civis e Políticos, de 16 de dezembro de 1966. Disponível em https://www.ohchr.org/SP/ProfessionalInterest/Pages/CCPR.aspx. Acesso em: 10 mar. 2019.

${ }^{16}$ Idem. Convenção Contra a Tortura e Outros Tratamentos ou Penas Cruéis, Desumanos ou Degradantes, de 10 de dezembro de 1984. Disponível em https://www.ohchr.org/sp/professionalinterest/pages/cat.aspx. Acesso em: 10 mar. 2019.

${ }^{17}$ ORGANIZAÇÃO DOS ESTADOS AMERICANOS. Convenção Americana sobre Direitos Humanos, de 22 de novembro $\quad$ de $\quad 1969 . \quad$ Disponível https://www.cidh.oas.org/basicos/portugues/c.convencao_americana.htm. Acesso em: 10 mar. 2019. 
domésticas, por seus julgamentos jurisdicionais e por sua atividade atípica regulatória de seus procedimentos, os instrumentos normativos e hermenêuticos oferecidos pelo direito internacional. Então, terá atuado em favor da expansão, no plano das relações nacionais, da garantia e da efetividade dos direitos internacionais. Ainda, terá agido em amplo cumprimento, também no âmbito nacional, das obrigações previstas pelo direito internacional e assumidas pelo Estado brasileiro. 


\section{CONCLUSÃO}

O direito internacional também deve ser realizado no plano das relações jurídicas nacionais. Suas normas podem reger os comportamentos havidos também no plano nacional. Para isso, o aparato de estado deve assim atuar, pela ação de seus agentes oficiais. É essa ação que faz a norma ser realizada. ${ }^{366}$

A justiça nacional tem relevante papel nessa atividade de fazer atuar o direito internacional. O termo justiça guarda relação mais estrita com a atuação desenvolvida pelos órgãos que compõem o poder judiciário brasileiro, ainda que tal atuação, na prática, não venha dissociada de prévia provocação realizada pelos demais atores que compõem o conceito orgânico amplo do termo.

Entre os agentes estatais, todavia, também parte significativa dos magistrados nacionais se priva de aplicar as normas consagradas pelo direito internacional, especialmente aquelas garantidoras de direitos humanos, na solução dos processos submetidos a seu julgamento. Ainda hoje, de maneira geral, vigora no âmbito do poder judiciário brasileiro a cultura do julgamento segundo a regência do direito estritamente nacional. De fato, os juízes nacionais brasileiros ainda são entusiastas e cultores da tradicional estrutura jurídica formada pelas normas editadas nacionalmente. Concebem a autossuficiência da legislação nacional típica, assim considerada aquela produzida mediante o procedimento legislativo constitucional próprio, pelos órgãos nacionais encarregados principais da edição das normas jurídicas, integrantes do poder legislativo (nacional, estadual, distrital e municipal). Em outras ocasiões, os magistrados nacionais prendem-se a conceitos vagos relacionados a interesses de ordem pública nacional, que impedem a aplicação mais franca das normas de direito internacional. Fazem-no ao sobreporem tais percepções à atividade de fazer atuar critérios de ordem pública

\footnotetext{
366 SUR, Serge. La créativité du droit international cours général de droit international public. RCADI, 363, 2012. p. 325. Refere o autor : « Si une règle de droit ne s'inscrit pas dans la réalité, soit qu'elle la consacre, soit qu'elle la façonne, elle devient au pire norme illusoire, au mieux norme dormante. Elle demeure utopique, peut-être intellectuellement séduisante, mais sans espoir. »
} 
relacionados com a própria aplicação do direito internacional, atividade com a qual o estado brasileiro se comprometeu internacionalmente.

Assim, o Estado brasileiro acaba por negar observância e solução doméstica que dê efetividade às normas de direito internacional que foram por ele próprio admitidas como adequadas à resolução de questões no plano internacional. Com isso, opõe-se contraditoriamente a dar ampla aplicação fática a dever ou à obrigação jurídica que convencionou observar e cumprir internacionalmente. O magistrado doméstico, ao assim se omitir, a um só tempo acaba por afirmar a violação cometida pelo poder público - parte demandada judicialmente, normalmente representada por atuação ou omissão do poder executivo - e por negar a realização, no contexto das relações jurídicas havidas em âmbito nacional, em prejuízo de seus jurisdicionados, do compromisso assumido pelo respectivo estado no plano internacional.

A atividade judicial direcionada à efetivação do direito, em um contexto de consciência criativa-valorativa e de comprometimento com a obtenção do resultado útil do processo, exprime a ideia semântica de efetivação, de implementação, dos valores prestigiados por certa norma jurídica. É dizer: essa atividade expressa o desejo de materialização de valores no plano dos fatos, de sua concretização experimental, de atribuição de máxima eficácia substantiva a esse valor, de promoção real do bem tutelado pela norma. Enfim, essa atividade busca a produção de resultados tangíveis concretamente, que atendam à expectativa de proteção jurídica que dá ensejo à própria existência da norma jurídica.

Os órgãos estatais, especialmente os órgãos integrantes do poder judiciário nacional, são estruturas com aptidão institucional e constitucional necessárias para fazer observar as condições impostas pelo direito internacional ao exercício da vontade soberana do estado. Nessa medida, a aplicação do direito internacional pelos atores nacionais, como meio de conter o exercício desmedido de poder do próprio estado, é meio de constante reafirmação da existência e da eficácia do direito internacional no plano doméstico.

No exercício desse mister, o estado, também o brasileiro, não declina de sua soberania quando aplica, às relações jurídicas havidas dentro de suas fronteiras, o direito 
internacional por ele admitido em suas relações internacionais. Ao contrário, a observância do direito internacional pelo estado confirma sua soberania, a qual é exercida pela permanente opção estatal de seguir a integrar a comunidade internacional e de seguir a observar as limitações admitidas decorrentes dessa opção.

Disso decorre a obrigação de ele criar e observar os meios necessários a respeitar e a aplicar, também no plano das relações jurídicas havidas em âmbito doméstico, as normas admitidas de direito internacional, atribuindo-lhes eficácia por intermédio da atuação conforme de sua estrutura oficial, inclusive da estrutura do poder judiciário nacional.

De fato, a soberania não pode mais representar a possibilidade de o estado agir livre e isoladamente na busca de seus exclusivos e egoísticos interesses, em detrimento de interesses coletivos transnacionais. As finalidades e interesses comuns aos estados impõem a adoção de uma postura de cooperação internacional de cada um deles. O exercício da soberania se expressa hoje justamente na adoção de postura cooperativa e atenta a interesses comuns, tutelados pelo direito internacional. Sob essa perspectiva, a tutela desses direitos também no plano nacional expressa verdadeiro ato de cooperação do estado e seu comprometimento em tornar efetivo o direito internacional também em ambiente doméstico, no plano das relações nacionais.

Nessa perspectiva, realizável é o direito a que corresponde um dever jurídico material e prontamente exigível de um terceiro. Será tanto mais exigível e prontamente efetivo juridicamente quanto maior for o acesso ao poder judiciário nacional e quanto mais diversificada for sua base normativa de ação e seus instrumentos de atuação institucional. É o poder judiciário a estrutura oficial por meio da qual o estado exerce a jurisdição e por intermédio de que lança mão do uso da força física legítima de que detém o monopólio, se necessário for e na justa proporção, para declarar a obrigação jurídica e para exigir seu cumprimento material.

Relevante instrumento de regulação da convivência social, o direito vem recebendo as mesmas inexoráveis influências de abertura externa que está a remodelar o próprio conceito de sociedade, antes restrita a unidades locais ou nacionais. Essa função operada pelo direito internacional vem recebendo posição de destaque nos 
diversos sistemas jurídicos nacionais, na medida em que é instrumento jurídico comum entre estados em busca de uma regulação materialmente única a questões que lhe são também comuns e atuais.

A relativização da noção de autossuficiência daquele direito produzido nacionalmente pelo estado, sem, contudo, automaticamente lhe negar a existência, a validade, a vigência e a eficácia, é resultado da globalização da vida e também do direito. A globalização, nessa perspectiva, opera como meio de aproximação e de inter-relação dos diversos sistemas jurídicos, cuja simbiose pressupõe o livre exercício da soberania de cada estado na aceitação de normas internacionais como meio de atender aos anseios comuns aos povos.

A atuação do magistrado nacional destaca-se nesse âmbito da globalização do direito. Sua atividade se dá no contexto da devida valoração do direito internacional contemporâneo, da profusão dos tratados celebrados entre estados e organizações internacionais e da necessidade da garantia, também no plano interno de cada estado, de observância dos direitos previstos nesses acordos.

$\mathrm{Na}$ ampla garantia da implementação de direitos contemplados pelo direito internacional, expressados em tratados ou em outras fontes, é crescente a atividade cooperativa do magistrado nacional, especialmente para impor a observância desses direitos pelo próprio estado e por seus agentes. Essa competência está, a propósito, diretamente relacionada com a relevância crescente atribuída aos direitos humanos, recorrentemente versados em instrumentos internacionais. Em contexto de destaque dos direitos humanos, ganhou também maior expressão a percepção ou o ideal de suas necessárias universalidade e supraestatalidade.

A atuação do magistrado nacional na busca da materialização de direitos, especialmente dos direitos humanos, abstratamente previstos e genericamente assegurados pelo direito internacional, nem sempre acompanhado de mecanismos efetivos e prontos de coerção em casos intersubjetivos concretos, é valioso meio de realização desses direitos. Note-se, a propósito, que a força da jurisdição nacional nesses casos incide justamente porque por certo houve um desatendimento prévio a esses direitos, circunstância que impôs o exercício do direito de ação pelo jurisdicionado 
lesado. Tal desrespeito prévio, no mais das vezes, é ensejado por ação ou por omissão intolerável do próprio estado, por ao menos um de seus órgãos e agentes públicos, de qualquer dos órgãos de sua estrutura.

A aplicação do direito internacional no plano nacional tem por objeto a promoção e a valorização normativa e funcional daquele direito, assim também a tutela dos bens jurídicos por ele amparados. Ainda quando as normas sob aplicação direta tenham sido inseridas no ordenamento interno, ou mesmo quando haja norma nacional com correspondência material àquela de direito internacional, o direito internacional e os valores por ele tutelados também se realizam com a efetivação daquele direito.

A efetivação social da norma mediante a elevação do grau de cumprimento social da norma, com a constatação de que de fato houve a majoração do número de condutas humanas em conformidade com os parâmetros fixados pela norma jurídica, é resultado relevante almejado pelo direito. Como ciência voltada à regulação de comportamentos jurídicos necessários a aviar a permanente convivência social pacífica, ao direito importa efetivamente guiar os comportamentos humanos que ele visa a regular. Para tanto, é relevante a atuação dos juízes nacionais e dos instrumentos de força que lhes estão institucionalmente e oficialmente postos à disposição. No plano das relações jurídicas havidas nacionalmente, a eficácia social do direito internacional pode ser potencializada pela atuação da jurisdição nacional e mesmo pela atuação administrativa dos órgãos do poder judiciário brasileiro. É mais uma força motriz que dá efetividade consequencial, que traz dinamismo real e realização material, ao direito internacional.

Por isso, essa perspectiva defendida à aplicação do direito internacional favorece sua unidade, seu progresso, sua coerência e sua institucionalização no plano das relações domésticas. Ela, ainda, põe em relevo a eficácia desse direito no âmbito nacional e confere reconhecimento à capacidade de o direito internacional disciplinar comportamentos potencialmente violadores de suas normas e valores, sobretudo aqueles comportamentos adotados pelos próprios órgãos do estado contra terceiros. Esse entendimento amplia a normatividade do direito internacional também ao âmbito das relações nacionais. Mais que isso, valida expectativas que se expressam normativamente e reafirma valores caros ao direito internacional e ao ambiente social nacional em que 
suas normas jurídicas devem ser aplicadas. Por decorrência, a aplicação do direito internacional no ambiente nacional escala o grau de justiciabilidade, também perante o poder judiciário doméstico, contra condutas que podem potencialmente violar suas normas no plano interno do estado, sobretudo em temas sensíveis aos direitos humanos, elevando a eficácia do princípio do acesso à justiça.

Enfim, a importância dessa atuação judicial nacional se expressa, também em outras possibilidades processuais ou normativas de funcionamento do poder judiciário brasileiro. Por meio dessa atuação, o juiz brasileiro pode dar resposta, também no âmbito interno, às demandas da globalização das relações sociais e jurídicas no que repercutem nos processos levados a seu julgamento e regulação normativa interna. Pode ainda estabelecer meios jurídicos de suprir eventuais omissões de tratamento da legislação doméstica, prestigiando materialmente as normas de direito internacional, bem assim admitir a ampliação do rol de direitos e, com isso a justiciabilidade, no âmbito nacional, de direitos mais detidamente normatizados pelas normas de direito internacional. Mais importante, pode também o juiz nacional brasileiro, com fundamento nesse seu dever de fazer atuar o direito internacional, corrigir comportamentos contraditórios do próprio Estado brasileiro, quando no plano internacional se compromete com uma prestação jurídica e no plano nacional não a observa.

O juiz nacional, quando se omite na aplicação do direito internacional, em verdade coloca o estado correspondente em posição jurídica de indevida violação desse direito. O estado, por intermédio da omissão desse seu agente oficial, acaba por se contradizer no plano doméstico em relação a comprometimento assumido no plano internacional, expressado por compromisso admitido perante outros estados e organismos internacionais. Esse comportamento contraditório do estado, por qualquer de seus agentes, representa intolerável violação do princípio de estoppel, expressão do princípio genérico da proibição de venire contra factum proprium.

Nessa atividade de aplicação do direito internacional, destaca-se a atuação de proteção dos direitos humanos pelos estados. A esse fim, ocupam posição de destaque o direito regional convencionado, de que é peça normativa central a Convenção americana de direitos humanos, bem assim a jurisprudência consultiva e contenciosa da Corte Interamericana de Direitos Humanos e a atuação da própria Comissão Interamericana 
como órgão central de coordenação das atividades em defesa dos direitos humanos no continente americano.

O norte oferecido pelo sistema interamericano na defesa dos direitos humanos passa, então, a guiar a atuação da jurisdição nacional. Essa interação ocorre quando a norma jurídica interamericana é invocada pela jurisdição nacional como fundamento de salvaguarda oficial dos direitos humanos contra resistências ao pleno respeito a esses direitos. Esse movimento, por consequência, promove o desenvolvimento de princípios e de obrigações estatais comuns aos países da região, cujo respeito torna-se objeto de monitoramento pelo sistema regional.

Importante atuação da justiça nacional no plano da efetivação do direito internacional se expressa ainda no cumprimento dos objetivos da Agenda 2030 das Nações Unidas para o desenvolvimento sustentável. As metas cometidas a esse objetivo 16 da Agenda guardam vínculo direto e nutrem expectativas reais com a adoção de medidas substantivas a serem postas em marcha pelas instituições oficiais dos estados e das organizações, em especial pelo poder judiciário nacional de cada um dos estados. Esse objetivo carrega consigo o legítimo compromisso assumido com a comunidade internacional pelos estados, em especial pela atuação de suas estruturas de justiça: compromisso de que ponham fim às ações ou às omissões violadoras dos direitos humanos ocorridas em cada um dos ambientes nacionais. Nesse contexto, evidencia-se a importância da atividade dos juízes nacionais, de todos os níveis de jurisdição, na cooperação para a realização do objetivo 16 da Agenda 2030 para o desenvolvimento sustentável. Cabe apresentar em que exata medida e com que preciso instrumental podem, e mesmo devem, os juízes nacionais, nos limites de seus legítimos poderes e de suas estritas competências institucionais, colaborar efetivamente para a realização desse objetivo.

Ainda expressão do comprometimento da justiça nacional com a efetivação do direito internacional é o atendimento da razoável duração do processo como meio de acesso material à justiça. O direito à razoável duração do processo efetivamente não pode ter sua eficácia limitada por contingências diversas, criadas pela indevida ação ou reprovável omissão do estado na organização de seus serviços essenciais. Portanto, a falta de estrutura de ordem humana, material, técnica ou orçamentária para fazer frente, 
em tempo razoável, à demanda de processos apresentados à jurisdição não autoriza a violação pelo estado do direito humano em apreço, com cuja efetivação se comprometeu em instrumentos internacionais.

A justiça brasileira deve atuar na efetivação do direito internacional. Deve fazêlo por intermédio de sua atuação jurisdicional e também por intermédio de sua atuação normativa.

$\mathrm{Na}$ medida em que disciplinam as atuações jurisdicional e administrativa dos órgãos da justiça brasileira, as competências executivas e normativas exercidas pelo Conselho Nacional de Justiça e pelos demais órgãos judiciários desfrutam de relevância destacada na efetivação dos direitos internacionais. É sobretudo a regência normativa de natureza vinculante que definirá o perfil de atuação administrativo e jurisdicional do poder judiciário brasileiro. É a delimitação e a ênfase material da norma de organização das atividades do poder judiciário que imprimirão, cabe dizer, o grau de comprometimento com que seus órgãos judiciários devem atuar na efetivação do direito internacional também em questões que estão intimamente relacionadas com suas próprias atuações institucionais.

Por fim, o exercício da atividade jurisdicional atenta e deferente ao direito internacional é uma das mais expressivas demonstrações oficiais, no âmbito dos atos internos, de boa-fé de que o estado está a buscar permanentemente o cumprimento, também no plano doméstico, dos compromissos internacionais por ele assumidos no plano das relações internacionais. A adoção de meios que permitam a efetiva projeção de efeitos jurídicos, também para dentro das fronteiras, das normas internacionais a que o estado se obrigou a cumprir no plano internacional expressa inequívoca demonstração de boa-fé e de envolvimento cooperativo do Estado brasileiro com o valores da comunidade internacional, demais de o legitima a exigir dos demais atores internacionais o mesmo comprometimento.

A atuação típica do poder judiciário conforme o direito internacional ganha relevância na medida em que ele é chamado a atuar justamente nos casos em que se observa ação ou omissão ilegítima do poder executivo na observância ou na efetivação do direito. Em percentual significativo dos casos judicializados, o poder judiciário é 
chamado a atuar para suprir omissão do poder executivo na efetivação de direitos ou, pior, para impor limitação à ação estatal violadora de direitos.

A análise dessas atividades típica e atípica do poder judiciário brasileiro demonstra que sua atuação normativa se tem destacado na efetivação do direito internacional, especialmente dos direitos humanos. Ainda que movida muitas vezes por atuações jurisdicionais prévias do Supremo Tribunal Federal brasileiro, cabe observar que a atuação normativa da justiça brasileira, especialmente do Conselho Nacional de Justiça, já oferece conjunto substancial de diplomas normativos infralegais que contemplam os direitos internacionais e que instrumentalizam sua efetivação pelos demais órgãos do poder judiciário brasileiro.

A atividade jurisdicional exercida pelos órgãos da justiça brasileira, por seu turno, vem elevando o grau de efetivação do direito internacional, por meio da invocação de suas normas como fundamentos jurídicos de decidir os casos submetidos a seu julgamento. Essa atuação ainda padece, contudo, de certo comedimento a ser vencido.

Por certo, também na atividade jurisdicional prestada pelo poder judiciário brasileiro a efetivação do direito internacional avançará rapidamente. 


\section{REFERÊNCIAS BIBLIOGRÁFICAS}

\section{Bases doutrinárias em meio físico}

ALLARD, Julie; GARAPON, Antoine. Les juges dans la mondialisation: la nouvelle révolution du droit. France: Seuil et La République des Idées, 2005.

ARISTÓTELES. A politica. Traduzido por Roberto Leal Ferreira. São Paulo: Martins Fontes, 2002.

BAPTISTA, Luiz Olavo. O Brasil e as influências do Direito Internacional. Boletim AASP, n. ${ }^{\circ}$ 3041. São Paulo: Rettec, jul. 2017, pp. 20-21.

BARROSO, Luís Roberto. A Dignidade da Pessoa Humana no Direito Constitucional Contemporâneo: a construção de um conceito jurídico à luz da jurisprudência mundial. Belo Horizonte: Fórum, 2013.

. O Direito Constitucional e a efetividade de suas normas, 9. ${ }^{\mathrm{a}}$ edição. Rio de Janeiro: Renovar: 2009.

BEDAQUE, José Roberto dos Santos. Comentários ao art. 273 do CPC. In: MARCATO, Antonio Carlos (org.). Código de Processo Civil Interpretado. São Paulo, Atlas, 2004.

BIEBER, Roland; CORNU, Anne. Le droit communautaire: une extranéité pour les ordres juridiques étatique? - L'exemple de la citoyenneté européenne. In: WYLER, Éric; PAPAUX, Alain (éd.). L'extranéité, ou le dépassement de lórdre juridique étatique : actes du colloque des 27 et 28 novembre 1997. Paris: Éditions A. Pédone, 1999. pp. 37-52.

BONDUELLE, Matthieu. Juger est um acte politique. Le Monde Diplomatique. Paris: septembre 2014.

CAMPILONGO, Celso Fernandes. Política, Sistema Jurídico e Decisão Judicial. São Paulo: Max Limonad, 2002. p. 173.

CAMUS, Albert. O Estrangeiro, 1. a ed. Antônio Quadros (tradutor). São Paulo: Abril Cultural, 1972, pp. 83 e 84. 
CANOTILHO, José Joaquim Gomes. Direito Constitucional e Teoria da Constituição. $7^{\mathrm{a}}$ ed. Coimbra: Edições Almedina, 1997.

CASELLA, Paulo Borba. Constituição e Direito Internacional. In: ; LIQUIDATO, Vera Lúcia Viegas. Direito da Integração. São Paulo: Quartier Latin, 2006. pp. 31-55. . Direito internacional no tempo antigo. São Paulo: Atlas, 2012. Direito internacional no tempo moderno de Suarez a Grócio. São Paulo: Atlas, 2014. . Evolução institucional do direito internacional: à luz do cinquentenário do conceito de direito de Hart (1961). Revista Brasileira de Filosofia, São Paulo, ano 60, n. ${ }^{\circ}$ 236, pp. 312-329, jan-jun/2011.

. Fundamentos do Direito Internacional Pós-Moderno. São Paulo: Quartier Latin, 2008

. Mercosul: exigências e perspectivas. São Paulo: LTr, 1996.

- Modalidades de Harmonização, Unificação e Uniformização do Direito - O Brasil e as Convenções Interamericanas de Direito Internacional Privado. In:

Araujo, Nadia de. Integração Jurídica Interamericana: as Convenções Interamericanas de Direito Internacional Privado (CIDIPs) e o direito brasileiro. São Paulo: LTr, p. 77-105, 1998.

CASSESE, Antonio. I diritti umani oggi. Bari: Editori Laterza, 2012.

CHIUZBAIAN, Gavril Iosif. Le juge et le droit international. Alemanha: Conseil de l'Europe, 1998.

COLOMBO, Gherardo. Sulle regole, $4 .^{\text {a }}$ ed.. Milano: Feltrinelli, 2012.

COSTA, Luciana da Silva. A revisitação do princípio da separação de poderes: dialogicidade e tensão como elementos conformadores da identidade constitucional brasileira. 2014. Tese (Doutorado em Direito) - Faculdade de Direito do Largo São Francisco, Universidade de São Paulo, São Paulo, 2014. 
DA SILVA, José Afonso. Curso de direito constitucional positivo. 24. ed. São Paulo: Malheiros, 2005.

DAILLIER, Patrick et al. Droit international public, 8. ${ }^{a}$ ed. Paris: LGDJ, 2009.

DALLARI, Dalmo de Abreu. Independência da magistratura e direitos humanos. Revista da Escola Superior da Magistratura de Sergipe, Aracajú, n. ${ }^{\circ}$ 01, p. 25-40, 2001.

DE ANDRADE, Carlos Drummond. O tempo Passa? Não passa. Amar se aprende amando, 24 ed. Rio de Janeiro: Record, 2001.

DEZALAY, Yves; David M. TRUBEK. A reestruturação global e o Direito. In: Direito e Globalização Econômica, 1. ' ed. Organizador José Eduardo Faria. São Paulo: Malheiros, 2010.

ERMACORA, Felix. Human rights and domestic jurisdiction (Article 2, Par.7, of the Charter). RCADI, 1968, tomo 124, pp. 371-451.

FERRAZ JR., Tércio Sampaio. Introdução ao Estudo do Direito. 6. ${ }^{\text {a }}$ ed.. São Paulo: Atlas, 2011.

FLOH, Fabio. Direito Internacional Contemporâneo: elementos para a configuração de um direito internacional na ordem internacional neo-westfaliana. In: CASELLA, Paulo Borba et al (org.). Direito Internacional, Humanismo e Globalidade: Guido Fernando Silva Soares. São Paulo: Atlas, 2008. p. 219-235.

GOLDSMITH, Jack L.; POSNER, Eric A. The limits of international law. New York: Oxford University Press, 2005.

GÓMEZ ROBLEDO, A. Le ius cogens internationale: sa genèse, sa nature, ses foctions. Haia: RCADI 172, 1981.

GUERRA, Sidney. Curso de Direito Internacional Público, 7. ed. São Paulo: Saraiva, 2013.

HÄBERLE, Peter. Estado constitucional cooperativo. Rio de Janeiro: Renovar, 2007. 
HELLER, Hermann. La soberanía. Cidade do México: Ediciones Fondo de Cultura Económica, 1995.

HESSEN, Johannes. Filosofia dos valores. 3. ${ }^{a}$ edição. Coleção Studium. Coimbra: Armênio Amado Editor, 1967.

IWASAWA, Yuji. Domestic application of International law. RCADI, 378, 2015.

JAYME, Erik. O Direito Internacional Privado do novo milênio: a proteção da pessoa humana face à globalização. In: MARQUES, Claudia Lima; ARAUJO, Nadia de. O novo direito internacional: estudos em homenagem a Erik Jayme. Rio de Janeiro: Renovar, 2005. p. 3-20.

JUBILUT, Liliana Lyra; AMARAL JUNIOR, Alberto do. O Direito Internacional dos Direitos Humanos e o Supremo Tribunal Federal. In: O STF e o Direito Internacional dos Direitos Humanos. São Paulo: Quartier Latin, p. 3-49, 2009.

KARNAL, Leandro. O direito de papel. O Estado de S. Paulo, São Paulo, 20 ago. 2017, Caderno 2, p. C7.

LAFER, Celso. Haia 110 anos. O Estado de São Paulo, São Paulo, 17 set. 2017. Caderno Espaço Aberto, p. 2.

LOCKE, John. Segundo Tratado Sobre o Governo Civil e Outros Escritos. Rio de Janeiro: Editora Vozes, 1994.

LUHMANN, Niklas. Sociologia do Direito. Vol. 1. Rio de Janeiro: Tempo Brasileiro, 1983.

MACHADO, Jónatas E. M. Direito Internacional: do paradigma clássico ao pós-11 de Setembro, 4. ${ }^{\text {a }}$ ed. Coimbra: Coimbra Editora, 2013.

MADROU, Robert. Magistrados e Feiticeiros na França do Século XVII: uma análise de Psicologia Histórica. São Paulo: Editora Perspectiva, 1979.

MAQUIAVEL, Nicolau. O príncipe. São Paulo: Penguin Classics Companhia das Letras, 2010 . 
MARINONI, Luiz Guilherme. A antecipação da tutela. 5. ed. São Paulo, Malheiros, 1999.

McCRUDDEN, C. Human dignity and judicial interpretation of human rights. The European Journal of International Law, 2008. 19(4), pp. 655-724. RAO Neomi. On the use and abuse of dignity in constitutional law. Columbia Journal of European Law, Spring, v. 2, n. 2, p. 201-256, 2008.

MELLO, Oswaldo Aranha Bandeira de. Princípios Gerais do Direito Administrativo, $3^{\mathrm{a}}$ edição, vol. 1. São Paulo: Malheiros Editores, 2007.

MENEZES, Wagner. Ordem Global e Transnormatividade. Ijuí: Ed. Unijuí, 2005.

MIRANDA, Jorge. Manual de Direito Constitucional: Direitos Fundamentais. Tomo IV. $5^{\mathrm{a}}$ ed. Coimbra: Coimbra Editora, 2012.

MONTESQUIEU, C.S. O Espírito das Leis. 3.ed. Trad. Cristina Murachco. São Paulo: Martins Fontes, 2005.

MOSCA, Lineide do Lago Salvador. Velhas e Novas Retóricas: convergências e desdobramentos. In: (org.). Retóricas de ontem e de hoje. São Paulo: Humanitas, 2001. pp. 11-54.

NERY JUNIOR, Nelson. Princípios do processo civil na Constituição Federal. $8^{\mathrm{a}}$ ed. rev., ampl., São Paulo: Editora Revista dos Tribunais, 2004.

ONUMA, Yasuaki. A Transcivilizational Perspective On International Law Questioning Prevalent Cognitive Frameworks in the Emerging Multi-Polar and MultiCivilizational Word of the Twenty-First Century. Boston: Martinus Nijhoff Publishers, 2010. p. 236.

ONUORA-OGUNO, Azubike. Leaving the woods to see the trees: locating and refocusing the activities of non-state actors towards the effective promotion of access to justice of persons with disabilities. In: African Disability Rights Yearbook, vol. 6, 2018. Pretória: Pretoria University Law Press, 2018. pp. 121-146.

PERELMAN, Chaïm. Ética e direito. São Paulo: Martins Fontes, 1996. 
PIOVESAN, Flávia. Direitos Humanos e o Direito Constitucional Internacional, 13. a ed. São Paulo: Saraiva: 2012.

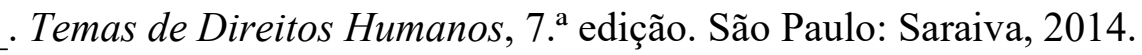

PLATÃO. A República. Tradução Maria Helena da Rocha Pereira. 9. ed. Lisboa: Fundação Calouste Gulbbenkian, 2001.

PRADELLE, Géraud de la. L'Homme Juridique. Grenoble (Fra): Press Universitaires, 1979.

QUINTANA, Mário. O Tempo. Esconderijos do tempo. São Paulo: Alfaguara / Companhia das Letras, 2013.

RANGEL, Vicente Marotta. Os conflitos entre o direito interno e os tratados internacionais. Separata da Revista da Faculdade de Direito da Universidade de São Paulo, ano LXII, fasc. II, 1967.

REZEK, Francisco. Direito internacional: curso elementar. São Paulo: Saraiva, 2010.

SARLET, Ingo Wolfgang. Dignidade da pessoa humana e direitos fundamentais na Constituição da República de 1988. Porto Alegre: Livraria do Advogado, 2002.

SCHERMERS, Henry G.; BLOKKER, Nils M. International Institutional Law: unity within diversity. $5^{\text {th }}$ rev. ed. Boston: Martinus Nijhoff Publishers, 2011.

SHULTZINER, Doron; CARMI, Guy. Human dignity in national constitutions: functions, promises and dangers. American Journal of Comparative Law, Washington/DC, n. 62, p. 461-490, 2014.

SICILIANOS, Linos-Alexandre. L'influence des droits de l'homme sur la structure du droit international. In: RGPID avril-juin/2012. Paris: A. Pedone, 2012.

SILVA, G. E. do Nascimento e; CASELLA, Paulo Borba; BITTENCOURT NETO, Olavo de Oliveira. Direito Internacional Diplomático: Convenção de Viena sobre relações diplomáticas na teoria e na prática, 4. ${ }^{\mathrm{a}}$ ed. São Paulo: Saraiva, 2012. 
SLAUGHTER, Anne-Marie; BURKE-WHITE, William. The Future of International Law Is Domestic (or, The European way of Law). Harvard International Law Journal. Cambridge, MA, v. 47, n. 2, p. 327-352, 2006.

SUR, Serge. La créativité du droit international. Cours général de droit international public. RCADI, 363, 2012.

. L'internalisation des conflits internes. In: WYLER, Éric; PAPAUX, Alain (éd.).

L'extranéité, ou le dépassement de lórdre juridique étatique : actes du colloque des 27 et 28 novembre 1997. Paris: Éditions A. Pédone, 1999.

TUBACH, Gaby. Le juge et le droit international. Alemanha: Conseil de l'Europe, 1998. p. 10 .

TUCCI, José Rogério Cruz e. Garantia do processo sem dilações indevidas. In: TUCCI, José Rogério Cruz e. Garantias constitucionais do processo civil - Homenagem aos 10 anos da Constituição Federal de 1988. São Paulo, RT, 1999.

VAREILLES-SOMMIÉRES, Pascoal de. Exception d'ordre public et régularité de la loi étrangère. 371 RCADI 157, 2014. p. 224.

WECKEL, Philippe. Rapport introductif. In : (org.). Le juge international et l'aménagement de l'espace : la spécifité du contentieux territorial. Paris : Editions A. Pedone, 1998. pp. 13-26.

WYLER, Éric; PAPAUX, Alain. Extranéité de valeurs et de systèmes en droit international privé et droit international public. In: (éd.). L'extranéité, ou le dépassement de lórdre juridique étatique : actes du colloque des 27 et 28 novembre 1997. Paris: Éditions A. Pédone, 1999. pp. 239-312.

ZAFFARONI, Eugenio Raúl. Estructuras Judiciales. Buenos Aires: EDIAR, 1994.

\section{Bases doutrinárias em meio eletrônico}

ARISTÓTELES. Ética a Nicômaco. Disponível em http://abdet.com.br/site/wpcontent/uploads/2014/12/\%C3\%89tica-a-Nic\%C3\%B4maco.pdf. Acesso em: 11 mar. 2019. 
BICUDO, Hélio. Arrazoado à exposição de motivos à emenda constitucional n 45, de 30 de dezembro de 2004. Diário do Congresso Nacional, Seção 1, 01.05.1992, p. 7849. Disponível https://www2.camara.leg.br/legin/fed/emecon/2004/emendaconstitucional-45-8dezembro-2004-535274-exposicaodemotivos-149264-pl.html. Acesso em: 20 mar. 2019. CAMPELO, Olívia Brandão Melo. A ideia de justiça na crise moral contemporânea. 2016. 119 f. Tese. (Doutorado em Direito) - Programa de Estudos Pós-Graduados em Direito, Pontifícia Universidade Católica de São Paulo, São Paulo, 2016. Disponível em https://tede2.pucsp.br/bitstream/handle/18830/2/O1\%c3\%advia\%20Brand\%c3\%a3o\%20 Melo\%20Campelo.pdf. Acesso em: 11 mar. 2019.

CASSESE, Antonio. Remarks on Scelle's Theory of "Role Splitting" (dédoublement fonctionnel) in International Law. In: European Journal of International Law (1990) 210231. Disponível em http://www.ejil.org/pdfs/1/1/1126.pdf. Acesso em: 30 nov. 2018.

COMPARATO, Fábio Konder. O papel do juiz na efetivação dos direitos humanos. Disponível em https://juslaboris.tst.jus.br/bitstream/handle/20.500.12178/111473/2001_comparato_fabi o_papel_juiz.pdf? sequence=1. Acesso em 10.10.2018.

CORRÊA, S. O. E MUNTARBHORN, V. (orgs.). Principios de Yogyakarta: princípios sobre a aplicação da legislação internacional de direitos humanos em relação à orientação sexual e identidade de gênero, de novembro de 2006. Disponível em: $<$ http://www.clam.org.br/pdf/principios_de_yogyakarta.pdf > . Acesso em: 22 jun. 2019.

CUNHA, José Ricardo et al. Direitos Humanos e Justiciabilidade: pesquisa no Tribunal de Justiça do Rio de Janeiro. São Paulo: SUR - Revista Internacional de Direitos Humanos, Número 3, Ano 2, p. 139-172, 2005. Disponível em https://sur.conectas.org/wp-content/uploads/2017/11/sur3-port-completa.pdf. Acesso em: 15 mai. 2019.

DALLARI, Dalmo de Abreu. O poder dos juizes. São Paulo: Saraiva, 1996 (pp. 83-84). Disponível em https://edisciplinas.usp.br/pluginfile.php/4305161/mod_resource/content/0/DALLARI\% 
2C\%20Dalmo.\%20O\%20Poder\%20dos\%20Ju\%C3\%ADzes.\%20Cap.\%20IX\%20\%28p

\%C3\%A1 ginas\%2080\%20a\%2084\%29.pdf. Acesso em: 12 mai. 2019.

HARDIN, Garrett. The tragedy of the commons. Science, New Series, Vol. 162, n. 3859, 1968, pp. 1243 - 1248. Disponível em: http://cecs.wright.edu/ swang/cs409/Hardin.pdf. Acesso em: 25 fev. 2017.

KEOHANE, Robert O., NYE JR., Joseph. Introduction. In: NYE JR, Joseph; DONAHUE, John D. Governance in a Globalizing World. Washington, D.C: The Brookings Institution, 2000. pp. 1-41) apud WELLS, Gary J. The Issue of Globalization - An Overview (RL30955). Washington, DC: Congressional Research Service, 2001. Disponível em https://digitalcommons.ilr.cornell.edu/cgi/viewcontent.cgi? article=1005\&context $=$ crs.

Acesso em: 22 mar. 2019.

MAYÓN, Carlos Alberto. El constitucionalismo internacional y los Estados nacionales. In. Revista del Colegio de Abogados de La Plata $n^{\circ}$ 65, Argentina. Disponível em http://www.la-razon.com/suplementos/la_gaceta_juridica/constitucionalismointernacional-nacionales_0_2210179051.html

ROMBOLI, Roberto. Los derechos fundamentales entre juez y legislador. In: Revista Judicial. San José de Costa Rica, n. ${ }^{\circ}$ 120, janeiro de 2017. pp. 15-26. Disponível em https://escuelajudicialpj.poder-

judicial.go.cr/Archivos/documentos/revs_juds/revista_120/index.html. Acesso em: 1 ago. 2018.

SCELLE, Georges. Précis de droit des gens: principes et systématique. Paris : Dalloz, impr. 2008. Apud CASSESE, Antonio. Remarks on Scelle's Theory of "Role Splitting" (dédoublement fonctionnel) in International Law. In: European Journal of International Law (1990) 210-231. Disponível em http://www.ejil.org/pdfs/1/1/1126.pdf. Acesso em: 30 nov. 2018.

SOARES, Guido Fernando Silva. Os Direitos Humanos e a proteção dos estrangeiros. In. Revista de Informação Legislativa. Brasília, ano 41, n. ${ }^{\circ}$ 162, pp. 169-204, abr./jun. 2004. Disponível em https://www2.senado.leg.br/bdsf/bitstream/handle/id/954/R16213.pdf? sequence=4\&isAllowed=y. Acesso em: 15 mai. 2019. 
WELLS, Gary J. The Issue of Globalization - An Overview (RL30955). Washington, DC: Congressional Research Service, 2001. Disponível em https://digitalcommons.ilr.cornell.edu/cgi/viewcontent.cgi?article=1005\&context=crs. Acesso em: 22 mar. 2019.

\section{Bases normativas}

BRASIL. Atos normativos.

- Constituição da República Federativa do Brasil. Disponível em http://www.planalto.gov.br/ccivil_03/constituicao/constituicao.htm. Acesso em diversas datas.

. Constituição da República. Emenda constitucional n. ${ }^{\circ} 45$, de 30 de dezembro de 2004. Disponível em http://www.planalto.gov.br/ccivil_03/constituicao/emendas/emc/emc45.htm. Acesso em: 05 ago. 2018.

Decreto $\mathrm{n}^{\circ} 3.413$, de 14 de abril de 2000. Promulga a Convenção sobre os Aspectos Civis do Sequestro Internacional de Crianças, concluída na cidade de Haia, em 25 de outubro de $1980 . \quad$ Disponível em http://www.planalto.gov.br/ccivil_03/decreto/D3413.htm. Acesso em: 10 mar. 2019.

Decreto $\mathrm{n}^{\circ} 4.377$, de 13 de setembro de 2002. Promulga a Convenção sobre a Eliminação de Todas as Formas de Discriminação contra a Mulher, de 1979, e revoga o Decreto $\mathrm{n}^{-} \mathbf{8 9 . 4 6 0}$, de 20 de março de 1984. Disponível em http://www.planalto.gov.br/ccivil_03/decreto/2002/D4377.htm. Acesso em: 22 mai. 2019.

Decreto $\mathrm{n}^{\circ}$ 7.030, de 14 de dezembro de 2009. Convenção de Viena sobre o Direito dos Tratados. Disponível em http://www.planalto.gov.br/ccivil_03/_Ato20072010/2009/Decreto/D7030.htm. Acesso em: 22 fev. 2009. 
Decreto-Lei n ${ }^{\circ} 3.689$, de 3 de outubro de 1941. Institui o Código de Processo Penal brasileiro. Disponível em http://www.planalto.gov.br/ccivil_03/decretolei/del3689.htm. Acesso em: 19 jun. 2019.

Decreto Legislativo n 496, de 17 de julho de 2009. Aprova o texto da Convenção de Viena sobre o Direito dos Tratados, concluída em Viena, em 23 de maio de 1969, $\begin{array}{lllllll}\text { ressalvados } & \text { os } & \text { arts. } & 25 & \text { e } & 66 . & \text { Disponível em }\end{array}$ https://www2.camara.leg.br/legin/fed/decleg/2009/decretolegislativo-496-17-julho2009-589661-publicacaooriginal-114586-pl.html. Acesso em: 22 fev. 2009.

. Lei $\mathrm{n}^{\circ}$ 6.015, de 31 de dezembro de 1973. Dispõe sobre os registros públicos, e dá outras providências. Disponível em http://www.planalto.gov.br/ccivil_03/leis/L6015compilada.htm. Acesso em: 23 jun. 2019.

. Lei $\mathrm{n}^{\circ} 11.798$, de 29 de outubro de 2008. Dispõe sobre a composição e a competência do Conselho da Justiça Federal, revoga a Lei n ${ }^{\circ} 8.472$, de 14 de outubro de 1992, e dá outras providências. Disponível em http://www.planalto.gov.br/ccivil_03/_ato2007-2010/2008/lei/L11798.htm. Acesso em: 10 mar. 2019.

Lei ${ }^{\circ} 12.106$, de 2 de dezembro de 2009. Cria, no âmbito do Conselho Nacional de Justiça, o Departamento de Monitoramento e Fiscalização do Sistema Carcerário e do Sistema de Execução de Medidas Socioeducativas e dá outras providências. Disponível em http:/www.planalto.gov.br/ccivil_03/_Ato2007-2010/2009/Lei/L12106.htm. Acesso em 19 jun. 2019.

. Lei $\mathrm{n}^{\circ}$ 13.146, de 6 de julho de 2015. Institui o Estatuto da Pessoa com Deficiência.

. Lei $\mathrm{n}^{\circ}$ 13.105/2015. Institui o Código de Processo Civil. Disponível em http://www.planalto.gov.br/ccivil_03/_ato2015-2018/2015/lei/113105.htm. Acesso em diversas datas. 
BRASIL. Conselho da Justiça Federal.

Resolução $n^{\circ} 42$, de 19 de dezembro de 2008. Aprova o Regimento Interno do $\begin{array}{lllll}\text { Conselho } & \text { da } & \text { Justiça } & \text { Federal. } & \text { Disponível em }\end{array}$ https://www.legisweb.com.br/legislacao/?id=109370. Acesso em: 30 mai. 2019.

Resolução $n^{\circ}$ 147, de 15 de abril de 2011. Institui o Código de Conduta do Conselho e da Justiça Federal de primeiro e segundo graus. Disponível em https://www2.cjf.jus.br/jspui/bitstream/handle/1234/44499/Res\%201472011.pdf? sequence=5. Acesso em: 25 jun. 2019.

Resolução $\mathrm{n}^{\circ}$ 530, de 25 de março de 2019. Dispõe sobre a instituição e a regulamentação do Alvará de Soltura Eletrônico no âmbito da Justiça Federal de primeiro $\begin{array}{lllll}\text { e } & \text { segundo } & \text { graus. } & \text { Disponível }\end{array}$ https://www2.cjf.jus.br/jspui/bitstream/handle/1234/50254/Res\%205302019.pdf? sequence=4. Acesso em: 25 jun. 2019.

Resolução $n^{\circ}$ 533, de 29 de março de 2019. Dispõe sobre a implantação do Sistema Nacional de Controle de Transferência de Preso (SNCTP) para as penitenciárias federais e dá outras providências. Disponível em https://www2.cjf.jus.br/jspui/bitstream/handle/1234/50264/Res\%205332019.pdf? sequence=6. Acesso em: 25 jun. 2019.

. Resolução n 542, de 8 de abril de 2019. Dispõe sobre a alteração da Resolução CJF n. 2, de 20 de fevereiro de 2008. Disponível em https://www.cjf.jus.br/publico/biblioteca/Res\%20542-2019.pdf. Acesso em: 10 jun. 2019. Resolução $\mathrm{n}^{\circ}$ 570, de 7 de agosto de 2019. Dispõe sobre a realização de teletrabalho e de trabalho em regime de auxílio de magistrado federal em localidade diversa de sua lotação, em caso de deficiência ou por motivo de saúde, em interesse próprio ou no interesse de cônjuge, companheiro ou dependentes. Disponível em http://www.in.gov.br/en/web/dou/-/resolucao-n-570-de-7-de-agosto-de-2019209843519. Acesso em: 2 set. 2019. 
BRASIL. Conselho Nacional de Justiça.

. Código de Ética da Magistratura Nacional. Aprovado em 6 ago. 2008. Disponível em https://www.cnj.jus.br/publicacoes/codigo-de-etica-da-magistratura. Acesso em: 3 jul. 2019.

. Portaria $\mathrm{n}^{\circ} 15$, de 8 de março de 2017. Institui a Política Judiciária Nacional de enfrentamento à violência contra as Mulheres no Poder Judiciário e dá outras providências. Disponível em http://www.cnj.jus.br/images/atos_normativos/portaria/portaria_15_08032017_1003201 7184034.pdf. Acesso em: 22 mai. 2019.

- Provimento $\mathrm{n}^{\circ}$ 12, de 6 de agosto de 2010. Disponível em http://www.cnj.jus.br/images/atos_normativos/provimento/provimento_12_06082010_2 6102012174319.pdf. Acesso em: 15 mai. 2019.

Provimento $\mathrm{n}^{\circ} 13$, de 3 de setembro de 2010. Dispõe sobre a emissão de certidão de nascimento nos estabelecimentos de saúde que realizam partos. Disponível em http://www.cnj.jus.br/images/stories/docs_corregedoria/provimentos/provimento_13.pdf . Acesso em: 15 mai. 2019.

- Provimento $\mathrm{n}^{\circ} 16$, de 17 de fevereiro de 2012. Disponível em http://www.cnj.jus.br/images/atos_normativos/provimento/provimento_16_17022012_2 6102012172402.pdf. Acesso em: 15 mai. 2019.

- Provimento $\mathrm{n}^{\circ}$ 19, de 29 de agosto de 2012. Disponível em http://www.cnj.jus.br/images/atos_normativos/provimento/provimento_19_29082012_2 6102012170128.pdf. Acesso em: 15 mai. 2019.

- Provimento $\mathrm{n}^{\circ}$ 26, de 12 de dezembro de 2012. Disponível em http://www.cnj.jus.br/images/atos_normativos/provimento/provimento_26_12122012_1 0012013164424.pdf. Acesso em: 15 mai. 2019.

Provimento n. ${ }^{\circ} 28$, de 5 de fevereiro de 2013. Dispõe sobre o registro tardio de nascimento, por Oficial de Registro Civil das Pessoas Naturais, nas hipóteses que disciplina. Disponível em http://www.cnj.jus.br/images/imprensa/provimento_tardio.pdf. Acesso em: 15 mai. 2019. 
Provimento $\mathrm{n}^{\mathrm{o}} 70$, de 12 de junho de 2018. Dispõe sobre abertura de matrícula e registro de terra indígena com demarcação homologada e averbação da existência de demarcação de área indígena homologada e registrada em matrículas de domínio privado incidentes em limites. http://www.cnj.jus.br/images/atos_normativos/provimento/provimento_70_12062018_1 3062018130257.pdf. Acesso em: 22 jun. 2019.

. Provimento $n^{\circ} 73$, de 28 de junho de 2018. Dispõe sobre a averbação da alteração do prenome e do gênero nos assentos de nascimento e casamento de pessoa transgênero no Registro Civil das Pessoas Naturais (RCPN). Disponível em https://www.cnj.jus.br/files/atos_administrativos/provimento-n73-28-06-2018corregedoria.pdf. Acesso em 22 jun. 2019.

. Provimento $n^{\circ}$ 85, de 19 de agosto de 2019. Dispõe sobre a adoção dos Objetivos de Desenvolvimento Sustentável, da Agenda 2030, pelas Corregedorias do Poder Judiciário e pelo Serviço Extrajudicial. Disponível em https://www.anoreg.org.br/site/2019/08/23/cnj-publica-provimento-85-sobrecumprimento-da-agenda-2030-da-onu/. Acesso em: 30 ago. 2019.

Recomendação $\mathrm{n}^{\circ} 33$, de 23 de novembro de 2010. Recomenda aos tribunais a criação de serviços especializados para escuta de crianças e adolescentes vítimas ou testemunhas de violência nos processos judiciais. Depoimento Especial. Disponível em https://www.cnj.jus.br/files/atos_administrativos/recomendao-n33-23-11-2010presidncia.pdf. Acesso em: 15 mai. 2019.

. Resolução $n^{\circ}$ 67, de 3 mar 2009. Aprova o Regimento Interno do Conselho Nacional de Justiça e dá outras providências. Disponível em http://www.cnj.jus.br/images/atos_normativos/resolucao/resolucao_comp_67_03032009 _22032019151610.pdf. Acesso em: 2 jun. 2019.

. Resolução $n^{\circ} 75$, de 12 de maio de 2009. Dispõe sobre os concursos públicos para ingresso na carreira da magistratura em todos os ramos do Poder Judiciário nacional. Disponível em http://www.cnj.jus.br/images/atos_normativos/resolucao/resolucao_75_12052009_2711 2015155433.pdf. Acesso em: 23 jun. 2019. 
- Resolução $\mathrm{n}^{\circ}$ 128, de 17 de março de 2011. Determina a criação de Coordenadorias Estaduais das Mulheres em Situação de Violência Doméstica e Familiar no âmbito dos Tribunais de Justiça dos Estados e do Distrito Federal. Disponível em http://www.cnj.jus.br/files/atos_administrativos/resoluo-n128-17-03-2011presidncia.pdf. Acesso em: 22 mai. 2019.

Resolução ${ }^{\circ}$ 165, de 16 de novembro de 2012. Dispõe sobre normas gerais para o atendimento, pelo Poder Judiciário, ao adolescente em conflito com a lei no âmbito na internação provisória e do cumprimento das medidas socioeducativas. Disponível em http://www.cnj.jus.br/images/atos_normativos/resolucao/resolucao_comp_165_1611201 2_25032019172022.pdf. Acesso em: 15 mai. 2019.

. Resolução $n^{\circ} 201$, de 3 de março de 2015. Dispõe sobre a criação e competências das unidades ou núcleos socioambientais nos órgãos e conselhos do Poder Judiciário e implantação do respectivo Plano de Logística Sustentável (PLS-PJ). Disponível em http://www.cnj.jus.br/images/atos_normativos/resolucao/resolucao_201_03032015_090 12019143611.pdf. Acesso em: 22 jun. 2019.

. Resolução ${ }^{\circ} 203$, de 23 de junho de 2015. Dispõe sobre a reserva aos negros, no âmbito do Poder Judiciário, de 20\% (vinte por cento) das vagas oferecidas nos concursos públicos para provimento de cargos efetivos e de ingresso na magistratura. Disponível em http://www.cnj.jus.br/files/atos_administrativos/resoluo-n203-23-06-2015presidncia.pdf. Acesso em: 30 jul. 2019.

. Resolução n 212, de 15 de dezembro de 2015. Institui o Fórum Nacional do Poder Judiciário para Monitoramento e Efetividade das Demandas Relacionadas à Exploração do Trabalho em Condições Análogas à de Escravo e ao Tráfico de Pessoas (FONTET), com o objetivo de elaborar estudos e propor medidas para o aperfeiçoamento do sistema judicial quanto ao tema. Disponível em http://www.cnj.jus.br/files/atos_administrativos/resoluo-n212-15-12-2015presidncia.pdf. Acesso em: 30 jul. 2019.

. Resolução $n^{\circ} 213$, de 15 de dezembro de 2015. Dispõe sobre a apresentação de toda pessoa presa à autoridade judicial no prazo de 24 horas. Disponível em 
https://www.cnj.jus.br/images/atos_normativos/resolucao/resolucao_213_15122015_231 12018141721.pdf Acesso em: 10 mar. 2019.

Resolução $n^{\circ} 230$, de 22 de junho de 2016. Orienta a adequação das atividades dos órgãos do Poder Judiciário e de seus serviços auxiliares às determinações exaradas pela Convenção Internacional sobre os Direitos das Pessoas com Deficiência e seu Protocolo Facultativo e pela Lei Brasileira de Inclusão da Pessoa com Deficiência por meio - entre outras medidas - da convolação em resolução a Recomendação CNJ 27, de 16/12/2009, bem como da instituição de Comissões Permanentes de Acessibilidade e Inclusão. Disponível em http://www.cnj.jus.br/files/atos_administrativos/resoluo-n23022-06-2016-presidncia.pdf. Acesso em: 23 jun. 2019.

. Resolução n. ${ }^{\circ} 252$, de 4 de setembro de 2018. Estabelece princípios e diretrizes para o acompanhamento das mulheres mães e gestantes privadas de liberdade e dá outras providências. Disponível em http://www.cnj.jus.br/files/atos_administrativos/resoluon252-04-09-2018-presidncia.pdf. Acesso em: 20 jul. 2019.

. Resolução n. ${ }^{\circ}$ 254, de 4 de setembro de 2018. Institui a Política Judiciária Nacional de enfrentamento à violência contra as Mulheres pelo Poder Judiciário e dá outras providências. http://www.cnj.jus.br/files/atos_administrativos/resoluo-n254-0409-2018-presidncia.pdf. Acesso em: 22 mai. 2019.

Resolução n. ${ }^{\circ}$ 255, de 13 de setembro de 2018. Institui a Política Nacional de Incentivo à Participação Institucional Feminina no Poder Judiciário. Disponível em http://www.cnj.jus.br/images/atos_normativos/resolucao/resolucao_255_04092018_050 92018143313.pdf. Acesso em: 22 mai. 2019.

. Resolução $\mathrm{n}^{\circ}$ 257, de 11 de setembro de 2018. Dispõe sobre a aplicação da Convenção de Haia sobre os aspectos civis do sequestro internacional de menores (1980). Disponível em http://www.cnj.jus.br/files/atos_administrativos/resoluo-n257-11-092018-presidncia.pdf. Acesso em: 15 mai. 2019.

. Resolução n. ${ }^{\circ}$ 279, de 26 de março de 2019. Dispõe sobre a concessão de licençapaternidade e de adotante para magistrados e servidores do Poder Judiciário brasileiro. Disponível em 
http://www.cnj.jus.br/images/atos_normativos/resolucao/resolucao_279_26032019_280 32019135821.pdf. Acesso em: 19 ago. 2019.

Resolução $n^{\circ}$ 284, de 5 de junho de 2019. Institui o Formulário Nacional de Avaliação de Risco para a prevenção e o enfrentamento de crimes e demais atos praticados no contexto de violência doméstica e familiar contra a mulher. Disponível em https://www.cnj.jus.br/images/atos_normativos/resolucao/resolucao_284_05062019_130 62019144703.pdf Acesso em: 20 jul. 2019.

. Resolução $\mathrm{n}^{\mathrm{o}}$ 287, de 25 de junho de 2019. Estabelece procedimentos ao tratamento das pessoas indígenas acusadas, rés, condenadas ou privadas de liberdade, e dá diretrizes para assegurar os direitos dessa população no âmbito criminal do Poder Judiciário.

Disponível em http://www.cnj.jus.br/images/atos_normativos/resolucao/resolucao_287_25062019 08072019182402.pdf. Acesso em: 20 ago. 2019.

. Resolução $n^{\circ} 288$, de 25 de junho de 2019. Define a política institucional do Poder Judiciário para a promoção da aplicação de alternativas penais, com enfoque restaurativo, em substituição à privação de liberdade. Disponível em http://www.cnj.jus.br/images/atos_normativos/resolucao/resolucao_288_25062019_ 08072019164730.pdf. Acesso em: 20 ago. 2019.

Resolução n. ${ }^{\circ}$ 289, de 14 de agosto de 2019. Dispõe sobre a implantação e funcionamento do Sistema Nacional de Adoção e Acolhimento - SNA e dá outras providências. Disponível em http://www.cnj.jus.br/images/atos_normativos/resolucao/resolucao_289_14082019_150 82019141539.pdf. Acesso em: 19 ago. 2019.

BRASIL. Conselho Superior da Justiça do Trabalho. Resolução $n^{\circ} 218$, de 23 de março de 2018. Dispõe sobre o uso da Língua Brasileira de Sinais (Libras) no âmbito da Justiça do Trabalho de primeiro e segundo graus para atendimento de pessoas surdas ou com deficiência auditiva. Disponível em https://juslaboris.tst.jus.br/bitstream/handle/20.500.12178/128269/2018_res0218_csjt.pd f? sequence=1\&isAllowed=y. Acesso em: 23 jul. 2019. 
Resolução Administrativa no 1909, de 20 de junho de 2017. Aprova o Regimento

Interno do Conselho Superior da Justiça do Trabalho. Disponível em https://juslaboris.tst.jus.br/bitstream/handle/20.500.12178/107030/2017_ra1909_rep01_a tualizado.pdf?sequence=3\&isAllowed=y. Acesso em: 23 jul. 2019.

- Sustentabilidade. Relação de atos normativos. Disponível em http://www.csjt.jus.br/web/cgest/sustentabilidade/atos-e-resolucoes. Acesso em: 23 jul. 2019.

CONSELHO DA EUROPA. Convenção europeia dos direitos do homem, de 4 de $\begin{array}{lllll}\text { novembro } & \text { de } & 1950 . & \text { Disponível em }\end{array}$ https://www.echr.coe.int/Documents/Convention_POR.pdf. Acesso em: 18 fev. 2019.

\section{NAÇÕES UNIDAS.}

- Agenda 2030 para o desenvolvimento sustentável. Disponível em https://nacoesunidas.org/pos2015/agenda2030/. Acesso em diversas datas.

Carta. Disponível em https://nacoesunidas.org/wp-content/uploads/2017/11/ACarta-das-Na\%C3\%A7\%C3\%B5es-Unidas.pdf. Acesso em 20 jul. 2019.

Convenção contra a tortura e outros tratamentos ou penas cruéis, desumanos ou degradantes, de 10 de dezembro de 1984. Disponível em https://www.ohchr.org/sp/professionalinterest/pages/cat.aspx. Acesso em: 10 mar. 2019.

- Convenção de Viena sobre o direito dos tratados. Disponível em https://www.oas.org/xxxivga/spanish/reference_docs/convencion_viena.pdf. Acesso em 23 mar. 2019.

. Convenção internacional sobre a eliminação de todas as formas de discriminação racial, de 21 de dezembro de 1965. Disponível em https://www2.camara.leg.br/atividadelegislativa/comissoes/comissoes-permanentes/cdhm/comite-brasileiro-de-direitoshumanos-e-politica-externa/ConvIntElimTodForDiscRac.html. Acesso em: 14 abr. 2019. Convenção relativa à proteção das crianças e à cooperação em matéria de adoção internacional, de 1993. Disponível em 
http://www.direitoshumanos.usp.br/index.php/Crian\%C3\%A7a/convencao-relativa-aprotecao-das-criancas-e-a-cooperacao-em-materia-de-adocao-internacional.html. Acesso em: 15 mai. 2019.

. Convenção sobre eliminação de todas as formas de discriminação contra a mulher, $\quad 1979 . \quad$ de $\quad$ Disponível em https://www.ohchr.org/sp/professionalinterest/pages/cedaw.aspx. Acesso em: 22 mai. 2019.

. Convenção sobre os aspectos civis do sequestro internacional de crianças, de 25 de outubro de 1980. Disponível em https://assets.hcch.net/docs/bbca6301-9847-470bac47-4635cb1 e7cbd.pdf. Acesso em: 10 mar. 2019.

- Convenção sobre os direitos da criança, de 1989. Disponível em https://www.unicef.org/brazil/convencao-sobre-os-direitos-da-crianca. Acesso em: 15 mai. 2019.

. Declaração universal dos direitos humanos, de 1948. Disponível em https://www.ohchr.org/EN/UDHR/Pages/Language.aspx?LangID=por. Acesso em: 22 mai. 2019.

. Pacto internacional sobre direitos civis e políticos, de 1966. Disponível em https://www.ohchr.org/SP/ProfessionalInterest/Pages/CCPR.aspx. Acesso em: 22 mai. 2019.

Protocolo facultativo à Convenção sobre a eliminação de todas as formas de discriminação contra a mulher, de 1999. Adotado pela Resolução A/54/4 da Assembleia Geral das Nações Unidas, em 6 de outubro de 1999. Disponível em https://www.ohchr.org/sp/professionalinterest/pages/opcedaw.aspx. Acesso em: 22 mai. 2019.

Protocolo facultativo à Convenção sobre os direitos da criança referente à venda de crianças, à prostituição infantil e à pornografia infantil, de 2000. Disponível em https://www.unicef.org/brazil/convencao-sobre-os-direitos-da-crianca\#protocolo_venda. Acesso em: 15 mai. 2019. 
Protocolo facultativo à Convenção sobre os direitos da criança relativo ao envolvimento de crianças em conflitos armados, de 2000. Disponível em https://www.unicef.org/brazil/convencao-sobre-os-direitos-dacrianca\#protocolo_conflitos. Acesso em: 15 mai. 2019.

. Regras das Nações Unidas para o tratamento de mulheres presas e medidas não privativas de liberdade para mulheres infratoras - Regras de Bangkok, de 2010. Disponível em https://www.unodc.org/documents/justice-and-prisonreform/Bangkok_Rules_ESP_24032015.pdf. Acesso em: 22 mai. 2019.

Regras mínimas padrão das Nações Unidas para a elaboração de medidas não privativas de liberdade - Regras de Tóquio, de 14 de dezembro de 1990. Disponível em https://www.cnj.jus.br/files/conteudo/arquivo/2016/09/6ab7922434499259ffca0729122b 2d38.pdf. Acesso em: 18 mai. 2019.

Regras mínimas das Nações Unidas para o tratamento dos reclusos - Regras Nelson Mandela (2015). Disponível em https://undocs.org/es/A/RES/70/175. Acesso em: 18 mai. 2019.

NAÇÕES UNIDAS. Organização Internacional do Trabalho.

. Convenção $\mathrm{n}^{\circ} 138$, que estabelece a idade mínima de 15 anos para admissão a $\begin{array}{lllll}\text { emprego ou } & \text { 1973. Disponível em }\end{array}$ https://www.ilo.org/brasilia/convencoes/WCMS_235872/lang--pt/index.htm. Acesso em: 15 mail. 2019.

. Convenção n. ${ }^{\circ}$ 182, sobre Proibição das Piores Formas de Trabalho Infantil e Ação Imediata para sua Eliminação, de 1999. Disponível em https://www.ilo.org/brasilia/convencoes/WCMS_236696/lang--pt/index.htm. Acesso em: 15 mai. 2019.

FRANÇA. Declaração de direitos do homem e do cidadão, de 1789. Disponível em http://www.direitoshumanos.usp.br/index.php/Documentos-anteriores-\%C3\%A0cria $\% \mathrm{C} 3 \% \mathrm{~A} 7 \% \mathrm{C} 3 \% \mathrm{~A} 30-$ da-Sociedade-das-Na\%C3\%A7\%C3\%B5es-at $\% \mathrm{C} 3 \% \mathrm{~A} 9-$ 1919/declaracao-de-direitos-do-homem-e-do-cidadao-1789.html. Acesso em: 30 mai. 2019. 
INGLATERRA. Declaração de direitos (Bill of Rights), de 1689. Disponível em http://www.dhnet.org.br/direitos/anthist/decbill.htm. Acesso em: 10 abr. 2019.

ORGANIZAÇÃO DOS ESTADOS AMERICANOS.

. Convenção Americana sobre Direitos Humanos, de 22 de novembro de 1969. Disponível em https://www.cidh.oas.org/basicos/portugues/c.convencao_americana.htm. Acesso em diversas datas.

- Convenção interamericana para prevenir, punir e erradicar a violência contra a mulher - Convenção de Belém do Pará, de 1994. Disponível em http://www.cidh.org/Basicos/Portugues/m.Belem.do.Para.htm. Acesso em: 22 mai. 2019. Adotada em Belém do Pará, Brasil, em 9 de junho de 1994, no Vigésimo Quarto Período Ordinário de Sessões da Assembleia Geral.

\section{Bases jurisprudenciais}

ARGENTINA. Corte Suprema. Casos: 275:235, 459; 294:220; 300:480; 307:1602; $312: 1706 ; 313: 367$.

BRASIL. Superior Tribunal de Justiça.

. CC 132.100/BA. Rel. Ministro João Otávio de Noronha, Segunda Seção, julgado em 25 fev. 2015, DJe de 14 abr. 2015.

CC n 133.010/MG. Segunda Seção, Relator o Ministro Marco Buzzi, julgado em 27 mai. 2015, publicado no Dje em 26 jun. 2015.

. HC 15.580/PB, Rel. Ministro Hamilton Carvalhido, Sexta Turma, julgado em 28 jun. 2001, DJ 24 set. 2001, p. 349.

. HC n ${ }^{\circ}$ 357.515/ES. Sexta Turma. Relatora a Ministra Maria Thereza de Assis Moura. Julgamento ocorrido em 18 out. 2016. Publicado no DJe de 08 nov. 2016. Disponível em https://ww2.stj.jus.br/processo/revista/documento/mediado/?componente=ATC\&sequen 
cial $=65952284 \&$ num_registro $=201601375104 \&$ data $=20161108 \&$ tipo $=91 \&$ formato $=P D$ F. Acesso em: 22 fev. 2019.

REsp n. ${ }^{\circ}$ 1.629.888, Segunda Turma, Relator o Ministro Mauro Campbell Marques, julgado em 8 fev. 2018, publicado no DJE de 21 fev. 2018. Inteiro teor disponível

em https://ww2.stj.jus.br/processo/revista/documento/mediado/?componente=ITA\&sequenc $\mathrm{ial}=1673620 \&$ num_registro $=201602594526 \&$ data $=20180221 \&$ formato $=P D F$. Acesso em: 3 jul. 2019.

. REsp n ${ }^{\circ}$ 1.791.098/RJ. Rel. Ministro Herman Benjamin, Segunda Turma, julgado em 23 abr. 2019, DJe 2 ago. 2019.

. RO-MS n. ${ }^{\circ}$ 20.572, Quinta Turma, Relatora a Ministra Laurita Vaz, julgado em 01.12.2009, publicado no DJE de 15.12.2009. Inteiro teor disponível em https://ww2.stj.jus.br/processo/revista/documento/mediado/?componente=ITA\&sequenc ial $=932833 \&$ num_registro $=200501430937 \&$ data $=20091215 \&$ formato $=$ PDF. Acesso em: 2 jul. 2019.

BRASIL. Superior Tribunal Militar.

. Apelação nº 0000005-67.1999.7.03.0103. Relator Ministro José Coêlho Ferreira. Data de julgamento: 23 mai. 2007.

. Correição Parcial no 0000123-19.2012.7.12.0012. Relator para o Acórdão Ministro Marcos Martins Torres. Data de Julgamento: 3 dez. 2012. Data de publicação: 26 fev. 2013.

BRASIL. Supremo Tribunal Federal.

. ADI n. ${ }^{\circ}$ 3.367-1/DF, Rel. Min. Cezar Peluso, distribuída em 9 dez. 2004, julgada em 13 abr. 2005 e publicada no Diário de Justiça de 22 set. 2006. Disponível em http://stf.jus.br/portal/diarioJustica/verDiarioProcesso.asp?numDj=192\&dataPublicacao $\mathrm{Dj}=05 / 10 / 2006 \&$ incidente $=2260590 \& \operatorname{codCapitulo}=2 \&$ numMateria $=8284 \& \operatorname{codMateria}=$ 8. Inteiro teor disponível em 
http://redir.stf.jus.br/paginadorpub/paginador.jsp?docTP=AC\&docID=363371. Acesso em: 21 mar. 2019.

. ADI 3.892 e ADI n 4.270. Relator o Ministro Joaquim Barbosa. Julgamento ocorrido em 14 mar. 2012, publicado no DJE de 25 set. 2012. Disponível em http://redir.stf.jus.br/paginadorpub/paginador.jsp?docTP=TP\&docID=2822197. Acesso em: 22 fev. 2019.

. ADI 4275. Relator min. Marco Aurélio, relator para acórdão min. Edson Fachin, Tribunal Pleno, julgado em 1. ${ }^{\circ}$ mar. 2018, processo eletrônico DJe-045 de 6 mar. 2019, publicado em 7 mar. 2019.

ADO 26. Órgão Plenário. Julgamento ocorrido em 13 jun. 2019. Pendentes de publicação. ATA de julgamento $n^{\circ} 22$, de 13 jun. 2019. DJE no 142, divulgado em 28 jun. 2019. Notícia oficial do julgado disponível em http://www.stf.jus.br/portal/cms/verNoticiaDetalhe.asp?idConteudo=414010. Acesso em: 15 jul. 2019.

. ADPF 172 MC-REF. Julgamento ocorrido em 10 jun. 2009, DJE de 21 ago. 2009, rel. min. Marco Aurélio.

. ADPF-MC 347 do Distrito Federal (Tribunal Pleno, Rel. Min. Marco Aurélio. j. em 9 set. 2015. p. 19 fev. 2016 no Dje de 18 fev. 2016.). Disponível em http://redir.stf.jus.br/paginadorpub/paginador.jsp?docTP=TP\&docID=10300665. Acesso em 16 out. 2018.

. AgReg. MI 772 AgR, relator o Ministro Celso de Mello, julgado em 24 out. 2007, publicado em 202 mar. 2009. Disponível em http://redir.stf.jus.br/paginadorpub/paginador.jsp?docTP=AC\&docID=582646. Acesso em: 22 fev. 2019.

AgReg. MS 31.695, Segunda Turma, Relator o Ministro Celso de Mello, julgado em 03.02.2015. Inteiro teor disponível em http://redir.stf.jus.br/paginadorpub/paginador.jsp?docTP=TP\&docID=8194186. Acesso em: 2 jul. 2019. . RE 466.343/RS. Tribunal Pleno. Relator o Ministro Cezar Peluso. $\mathrm{DJE} \mathrm{n}^{\circ} 104$ de 04.06.2009. Publicado em 05.06.2009. Ementário n² 2363-6. 
. AgR - RE 229.806/ PE. Plenário, Relator o Ministro Teori Zavascki, julgado em 1 ago. 2013, publicado no Dje 152 de 7 ago. 2013, divulgado em 6 ago. 2013

AI 554.858 AgR-AgR-ED-ED. $1^{\text {a }}$ Turma, Rel. Min. Ayres Britto, j. 27-10-09, DJE de 11-12-09.

AI 716.970 AgR-ED-AgR-ED. 1ª Turma, Rel. Min. Ricardo Lewandowski, j. 911-10, DJE 30-11-10.

. AI 759.450 ED. $2^{\mathrm{a}}$ Turma, Rel. Min. Ellen Gracie, j. $1^{\mathrm{o}}-12-09$, DJE 18-12-09.

. AP 470 QO4. Plenário, Rel. Min. Joaquim Barbosa, j. 10-6-2009, DJE de 2-102009.

AP 477 AgR, Plenário, Rel. Min. Ricardo Lewandowski, j. 7-10-2010, DJE de 25-10-2010.

. AP 863 ED/SP. $1^{\text {a }}$ Turma, Rel. Min. Edson Fachin, j. 10/10/2017, DJE 28-112017.

ARE 766.618. Relator Ministro Roberto Barroso, Tribunal Pleno, julgado em 25 mai. 2017, acórdão eletrônico DJe-257.

. HC 89.622. Rel. Min. Ayres Britto, j. 3-6-2008, 1ª Turma, DJE de 19-9-2008.

. HC 91.041. $1^{\text {a }}$ Turma, Rel. para o Acórdão o Min. Ayres Britto, j. 5-6-07, DJ 178-07).

. HC 91.408. $2^{\mathrm{a}}$ Turma, Rel. Min. Eros Grau, j. 14-8-2007, DJ de 26-10-2007.

. HC 94.170. $1^{\text {a }}$ Turma, Rel. Min. Menezes Direito, j. 10-6-2008, DJE de 8-8-2008.

. HC 96.504. 1ª Turma, Rel. Min. Cármen Lúcia, j. 30-6-09, DJE 23-10-09.

. HC 96.511. $1^{\text {a }}$ Turma, Rel. Min. Menezes Direito, j. 28-4-2009, DJE de 29-52009.

. HC 97.461. $2^{\mathrm{a}}$ Turma, Rel. Min. Eros Grau, j. 12-5-2009, DJE de 1º-7-2009.

. HC 98.163. 2 ${ }^{\mathrm{a}}$ Turma, Rel. Min. Ellen Gracie, j. 6-10-09, DJE 29-10-2009. 
. HC 100.299. $1^{\text {a }}$ Turma, Rel. Min. Ricardo Lewandowski, j. 2-2-10, DJE 5-3-10.

. HC 101.693. $1^{\text {a }}$ Turma, Rel. para o Acórdão o Min. Dias Toffoli, j. 16-6-2010, DJE de 24-11-2010.

. HC 101.726. 2a Turma, Rel. min. Ellen Gracie, j. 22-6-2010, DJE de 17-9-2010.

. HC 102.457. $2^{\mathrm{a}}$ Turma, Rel. Min. Celso de Mello, j. 3-8-10, DJE 1º-8-13.

. HC 141.949. Relator Ministro Gilmar Mendes, Segunda Turma, julgado em 13/03/2018, processo eletrônico DJe-077 divulg. 20 abr. 2018, public. 23 abr. 2018.

. HC 143.641, rel. min. Ricardo Lewandowski, 2a Turma, j. 20 fev. 2018.

. HC 151.523, Relator Ministro Edson Fachin, Segunda Turma, julgado em 27 nov. 2018, processo eletrônico DJe-263 divulg. 6 dez. 2018, public. 7 dez. 2018.

. MS 23.841 AgR-ED-ED. $1^{\text {a }}$ Turma, Rel. Min. Eros Grau, j. 18-12-06, DJ 16-207.

. Rcl 5.758. Plenário, Rel. Min. Carmen Lúcia, j. 13-5-09, P, DJE 7-8-09.

. Rcl 22.328, Relator Ministro Roberto Barroso, Primeira Turma, julgado em 6 mar. 2018, processo eletrônico DJe-090 divulg. 9 mai. 2018, public. 10 mai. 2018.

. RE 247.416 EDv-ED-AgR. Plenário, Rel. Min. Celso de Mello, j. 29-6-00, DJ de 24-11-00.

. RE 569.476 AgR. Plenário, voto da Rel., Min. Ellen Gracie, j. 2-4-2008, DJE de 25-4-2008.

. RE 670.422. Relator o min. Dias Toffoli. Plenário, 15 ago. 2018. Disponível em http://stf.jus.br/portal/diarioJustica/verDiarioProcesso.asp?numDj=169\&dataPublicacao $\mathrm{Dj}=20 / 08 / 2018 \&$ incidente $=4192182 \& \operatorname{codCapitulo}=2 \&$ numMateria $=22 \& \operatorname{codMateria}=3$. Acesso em: 06 jun. 2019. 
RE 778.889, rel. min. Roberto Barroso, P, j. 10-3-2016, DJE de $1^{\circ}$-8- 2016, Tema 782.

. RE 1.013.740 AgR-ED/SC, $2^{\text {a }}$ Turma, Rel. Min. Ricardo Lewandowski, j. 2108-2017, DJE de 29-08-2017.

. SL n ${ }^{\circ} 1248$ e $\mathrm{Rcl} \mathrm{n}^{\circ}$ 36742. STF suspende decisão que permitia apreensão de livros na Bienal do RJ. Notícia de 8 set. 2019. Disponível em http://noticias.stf.jus.br/portal/cms/verNoticiaDetalhe.asp?idConteudo=422875. Acesso em: 8 set. 2019.

BRASIL. Tribunal Regional Federal da Terceira Região.

. AI 481.169, 0021150-95.2012.4.03.0000, Primeira Turma, Rel. Desembargadora Federal Vesna Kolmar, julgado em 21 mai. 2013, e-DJF3 Judicial 1 de 28 mai. 2013.

. AI 589.913, 0018957-68.2016.4.03.0000, Quarta Turma Rel. Juiz Convocado Ferreira da Rocha, julgado em 7 mar. 2018, e-DJF3 Judicial 1 de 19 abr. 2018.

Ap. $\mathrm{n}^{\mathrm{o}}$ 58.381, 0003569-27.2007.4.03.6181, Primeira Turma, Rel. Juiz Convocado Márcio Mesquita, julgado em 19 set. 2017, e-DJF3 Judicial 1 de 25 set. 2017. Ap 280.511, 0007667-46.2003.4.03.6100, Quarta Turma, Rel. Desembargador Federal Andre Nabarrete, julgado em 15 ago. 2018, e-DJF3 Judicial 1 de 4 set. 2018.

. Ap 1.897.274. Décima Turma, 0018317-58.2008.4.03.6301, Rel. Desembargadora Federal Lucia Ursaia, julgado em 26 fev. 2019, e-DJF3 Judicial 1 de 8 mar. 2019.

. Ap.Civ. n. ${ }^{\circ}$ 1.607.772, processo . $^{\circ}$ 0001155-31.2010.4.03.6123, Oitava Turma, Relator o Desembargador Federal Luiz Stefanini, julgado em 19.02.2018, publicado no eDJF3 de 05.03.2018. Inteiro teor disponível em http://web.trf3.jus.br/acordaos/Acordao/BuscarDocumentoGedpro/6564396. Acesso em: 2 jul. 2019. 
ApCiv 1.607.695, 0005514-51.2010.4.03.6114, Décima Primeira Turma, Rel. Desembargador Federal Fausto De Sanctis, julgado em 22 ago. 2019, e-DJF3 Judicial 1 de 30 ago. 2019.

. Ap 1.733.984, 0000007-96.2012.4.03.6128, Primeira Turma, Rel. Desembargador Federal Valdeci dos Santos, julgado em 26 mar. 2019, e-DJF3 Judicial 1 de 4 abr. 2019.

ApCiv 1.899.464, Terceira Turma, 0018914-09.2012.4.03.6100, Rel. Desembargador Federal Nelton dos Santos, julgado em 7 ago. 2019, e-DJF3 Judicial 1 de 14 ago. 2019.

ApCiv 2.284.215, 0005777-18.2016.4.03.6100, Segunda Turma Rel. Desembargador Federal Cotrim Guimarães, julgado em 4 jun. 2019, e-DJF3 Judicial 1 de 13 jun. 2019, entre tantos outros.

HC 41.706/SP, 0021671-11.2010.4.03.0000, Segunda Turma, Relatora a Desembargadora Federal Cecília Mello, julgamento ocorrido em 28 out. 2010, fonte eDJF3 judicial 1 de 07.10.2010, p. 117.

HC n. ${ }^{\circ}$ 5009833-68.2019.4.03.0000/SP, Décima Primeira Turma, Relator o Desembargador Federal Jose Marcos Lunardelli, julgamento ocorrido em 22 mai. 2019, Intimação via sistema em 24.05.2019. Disponível em http://web.trf3.jus.br/base-textual. Acesso em: 15 jun. 2019.

TRIBUNAL SUPERIOR DO TRABALHO. RR-1076-13.2012.5.02.0049. $7^{\mathrm{a}}$ Turma, Relator Ministro Cláudio Mascarenhas Brandão, DEJT 03/05/2019.

TRIBUNAL SUPERIOR ELEITORAL. Rcl nº 318. Relator(a) Min. Luiz Carlos Madeira, Diário de justiça, Volume 1, de 17 set. 2004, p. 176.

CONSELHO DA EUROPA. Corte Europeia de Direitos Humanos.

Wemhoff c. Allemagne (Requête no 2122/64) Arrêt Strasbourg, 27 juin 1968. Disponível em http://www.echr.coe.int/Pages/home.aspx?p=home\&c=fre. Acesso em: 19 fev. 2019. 
Baraona c. Portugal, p. 18, § 46. Publicado em 8 de julho de 1987. Disponível em http://www.refworld.org/cases,ECHR,42b2d37c4.html. Acesso em: 14 jan. 2019.

Case Of Al-Adsani v. The United Kingdom, Application n 35763/97, judgement on 21 nov. 2011. Disponível em http://hudoc.echr.coe.int/eng?i=001-59885. Acesso em: 25 mai. 2018.

- Panju c. Bélgica. Julgado em 23 septembre 2014. Disponível em http://www.echr.coe.int/Pages/home.aspx?p=home\&c=fre. Acesso em: 15 jan. 2019.

C. P. e outros contra França, §30. Disponível em http://www.echr.coe.int/Pages/home.aspx?p=home\&c=fre. Acesso em: 14 jan. 2019.

. Case of Tim Henrik Bruun Hansen v. Denmark, (application no. 51072/15, Fourth Section, judgment 9 July 2019. Disponível em https://hudoc.echr.coe.int/eng\#\{\%22itemid\%22:[\%22001-194318\%22]\} e http://hudoc.echr.coe.int/eng?i=001-194318. Acesso em: 10 jul. 2019.

ESPANHA. Tribunal Constitucional. Sentencia 58/1999 (Ponente el Magistrado don Guillermo Jiménez Sánchez, decisión de 12-04-1999, BOE núm. 118, de 18 de mayo de 1999). Disponível em https://www.tribunalconstitucional.es/en/Paginas/default.aspx. Acesso em: 20 jan. 2019.

NAÇÕES UNIDAS. Corte Internacional de Justiça.

Réserves à la convention pour la prévention et la répression du crime de génocide, avis consultatif, C.I.J. Recueil 1951, p. 23;

. Timor oriental (Portugal c. Australie), C.I.J. Recueil 1995, p. 102, par. 29;

Application de la convention pour la prévention et la répression du crime de génocide (Bosnie-Herzégovine c. Yougoslavie), exceptions préliminaires, arrêt, C.I.J. Recueil 1996 (II), p. 616, par. 31;

Licéité de l'emploi de la force (Yougoslavie c. Espagne), mesures conservatoires, ordonnance du 2 juin 1999, C.I.J. Recueil 1999 (II), p. 772, par. 32-33; 
Activités armées sur le territoire du Congo (nouvelle requête: 2002, République démocratique du Congo c. Rwanda), mesures conservatoires, ordonnance du 10 juillet 2002, C.I.J. Recueil 2002, p. 241, par. 57;

. Activités armées sur le territoire du Congo (République démocratique du Congo c. Ouganda), CIJ Recueil 2006, p. 32, § 64;

ORGANIZAÇÃO DOS ESTADOS AMERICANOS. Corte Interamericana de Direitos Humanos.

. Caso Neira Alegría e outros vs. Perú. Sentença de 11 de dez. 1991 (exceções preliminares). https://summa.cejil.org/es/document/dr93zlfy4dlyds4i?page=4. Acesso em 2 jun. 2019.

. Caso Genie Lacayo vs. Nicarágua, de 29 jan. 1997. Disponível em http://www.corteidh.or.cr/. Acesso em: 14 jan. 2019.

- Caso Suárez Rosero vs. Ecuador, de 12 nov. 1997. Disponível em http://www.corteidh.or.cr/. Acesso em: 14 jan. 2019.

. Caso Valle Jaramillo y otros vs.Colombia, de 27 nov. 2008. Disponível em http://www.corteidh.or.cr/. Acesso em: 16 jan. 2019.

. Caso Kawas Fernández vs.Honduras, de 3 abr. 2009. Disponível em http://www.corteidh.or.cr/. Acesso em: 16 jan. 2019.

. Caso Usón Ramírez vs. Venezuela. Sentença de 20 de novembro de 2009. Série

C, $\quad \mathrm{n}^{\mathrm{o}} 207 . \quad$ Disponível em
http://www.corteidh.or.cr/docs/casos/articulos/seriec_207_esp.pdf. Acesso em: 20 jul. 2019.

. Caso Garibaldi ("guerrilha do araguaia") vs. Brasil. Voto fundamentado do juiz ad hoc Roberto de Figueiredo Caldas à sentença de 24 de novembro de 2010. Série C, 219. Disponível em http://www.corteidh.or.cr/docs/casos/articulos/seriec_219_por.pdf (p. 117 e ss.). Acesso em: 20 jul. 2019. 
. Caso Gudiel Álvarez y otros - "Diario Militar” - vs. Guatemala. Sentença de 20 de novembro de 2012 (fundo, reparações e custas). Série C, 253. Disponível em http://www.corteidh.or.cr/docs/casos/articulos/seriec_253_esp1.pdf. Acesso em: 22 jul. 2019.

. Caso de la Masacre de Santo Domingo vs. Colombia. Sentença de 30 nov. 2012 (exceções preliminaries, fundo e reparações). Série 259, Disponível em http://www.corteidh.or.cr/docs/casos/articulos/seriec_259_esp.pdf. Acesso em 20 jul. 2019.

Caso Mendoza y otros vs. Argentina. Sentença de 14 de maio de 2013 (exceções, fundo e reparações). Série C, 260. Disponível em http://www.corteidh.or.cr/docs/casos/articulos/seriec_260_esp.pdf. Acesso em: 21 jul. 2019.

. Caso Liakat Ali Alibux vs. Surinam. Sentença de 30 de janeiro de 2014 (exceções, fundo, reparações e custas). Série C, 276. Disponível em http://www.corteidh.or.cr/docs/casos/articulos/seriec_276_esp.pdf. Acesso em: 21 jul. 2014.

. Caso Rochac Hernández y otros vs. El Salvador. Sentença de 14 de outubro de 2014 (fundo, reparações e custas). Série C, 285. Disponível em http://www.corteidh.or.cr/docs/casos/articulos/seriec_285_esp.pdf. Acesso em: 21 jul. 2019.

Caso Ruano Torres y otros vs. El Salvador. Sentencia de 5 de octubre de 2015 (Fondo, Reparaciones y Costas). Série C, n. ${ }^{\circ}$ 303, esp. Disponível em http://www.corteidh.or.cr/docs/casos/articulos/seriec_303_esp.pdf. Acesso em: 20 fev. 2019.

. Caso Ramírez Escobar e outros vs. Guatemala. Sentença de 9 de março de 2018 (fundo, reparações e custas). Série $\mathrm{C} \quad$ n. ${ }^{\circ}$ 351. Disponível em http://www.corteidh.or.cr/docs/casos/articulos/seriec_351_esp.pdf. Acesso em 16 mai. 2019. 
. Caso Herzog e outros vs. Brasil. Exceções Preliminares, Mérito, Reparações e

Custas. Sentença de 15 de março de 2018. Série C, n. ${ }^{\circ}$ 353. Disponível em http://www.corteidh.or.cr/docs/casos/articulos/seriec_353_por.pdf. Acesso em 26 mar. 2019.

Opinião Consultiva $\mathrm{OC} \mathrm{n}^{\circ} 18$, de 17 set. 2003. Trata da condição jurídica e dos direitos dos migrantes não documentados, solicitada pelos Estados Unidos Mexicanos. Disponível em https://www.acnur.org/fileadmin/Documentos/BDL/2003/2351.pdf. Acesso em: 20 jun. 2019.

Opinião Consultiva OC n 21. Resolução de 19 de agosto de 2014. Disponível em http://www.corteidh.or.cr/docs/opiniones/seriea_21_por.pdf. Acesso em: 23 jul. 2019.

\section{Bases diversas}

BRASIL. Conselho Nacional de Justiça.

- Banco nacional de monitoramento de prisões. Disponível em https://www.cnj.jus.br/sistema-carcerario-e-execucao-penal/cadastro-nacional-depresos-bnmp-2-0. Acesso em: 19 de jun. 2019.

- Cadastro Nacional de mulheres presas grávidas e lactantes. Disponível em https://paineis.cnj.jus.br/QvAJAXZfc/opendoc.htm?document=qvw_1\%5Cpainelcnj.qvw \&host=QVS\%40neodimio03\&anonymous=true\&sheet=shIGLMapa. Acesso em: 10 ago. 2019.

- Cartilha da pessoa presa, 2. ${ }^{\mathrm{a}}$ edição. 2012. Disponível em http://www.cnj.jus.br/images/programas/comecar-de-

novo/publicacoes/cartilha_da_pessoa_presa_1_portugues_3.pdf. Ver ainda Cartilha da mulher presa, 2. ${ }^{\mathrm{a}}$ edição. 2012. Disponível em http://www.cnj.jus.br/images/programas/comecar-denovo/publicacoes/cartilha_da_mulher_presa_1_portugues_4.pdf. Acesso em: 19 de jun. 2019. 
CNJ apoia campanha no Dia Mundial de Combate ao Trabalho Infantil. 12 jun. 2017. Disponível em http://www.cnj.jus.br/noticias/cnj/84937-cnj-apoia-campanha-nodia-mundial-de-combate-ao-trabalho-infantil. Acesso em: 16 mai. 2019.

CNJ e Childhood renovam parceria para humanizar depoimento de crianças. 9 nov. 2018. Disponível em http://www.cnj.jus.br/noticias/cnj/87988-cnj-e-childhoodrenovam-parceria-para-humanizar-depoimento-de-criancas. Acesso em 15 mai. 2019.

Diagnóstico da Participação Feminina no Poder Judiciário, 2019. Disponível em http://www.cnj.jus.br/files/conteudo/arquivo/2019/05/cae277dd017bb4d4457755febf5ee d9f.pdf. Acesso em: 20 jun. 2019.

- Fórum Nacional da Infância e da Juventude (Foninj). Disponível em http://www.cnj.jus.br/noticias/cnj/89411-forum-da-infancia-e-da-juventude-discutecondicao-de-pessoas-intersexo. Acesso em: 30 ago. 2019.

Fórum Nacional do Poder Judiciário para Monitoramento e Efetividade das Demandas Relacionadas à Exploração do Trabalho em Condições Análogas à de Escravo e ao Tráfico de Pessoas (FONTET). Disponível em http://www.cnj.jus.br/programas-eacoes/assuntos-fundiarios-trabalho-escravo-e-trafico-de-pessoas/fontet. Acesso em: 30 jul. 2019.

. Plenário aprova criação do Sistema Nacional de Adoção e Acolhimento. 6 ago. 2019. Disponível em http://www.cnj.jus.br/noticias/cnj/89349-plenario-aprovaresolucao-sobre-sistema-nacional-de-adocao-e-acolhimento. Acesso em: 19 ago. 2019.

BRASIL. Supremo Tribunal Federal.

Ações de acessibilidade no STF promovem inclusão social de pessoas com deficiência. Notícia de 5 ago. 2019. Disponível em http://www.stf.jus.br/portal/cms/verNoticiaDetalhe.asp?idConteudo=418448. Acesso em 15 ago. 2019. 
Pacto une Três Poderes contra violência doméstica à mulher. Notícia de 7 ago. 2019. Disponível em http://www.cnj.jus.br/noticias/cnj/89355-pacto-une-tres-poderescontra-violencia-domestica-a-mulher. Acesso em: 15 ago. 2019.

DALÍ, Salvador. A Persistência da Memória, 1931. Museu de Arte Moderna (MoMa), em Nova York. Disponível em https://www.moma.org/learn/moma_learning/1168-2. Acesso em: 20 jan. 2019.

LEWANDOWSKI, Ricardo. Discurso de posse na presidência do STF. Disponível em http://www.stf.jus.br/arquivo/cms/publicacaoPublicacaoInstitucionalPossePresidencial/a nexo/Plaqueta_Posse_Presidencial_Ricardo. Acesso em: 16 out. 2018.

OEA. Comissão Interamericana de Direitos Humanos. CIDH expressa sua profunda preocupação frente à alarmante prevalência de assassinatos de mulheres em razão de estereótipo de gênero no Brasil. Comunicado à imprensa de 4 fev 2019. Disponível em http://www.oas.org/pt/cidh/prensa/notas/2019/024.asp. Acesso em: 20 jun. 2019.

\section{NAÇÕES UNIDAS.}

Comentários aos Princípios de Bangalore de Conduta Judicial / Escritório Contra Drogas e Crime; tradução de Marlon da Silva Maia, Ariane Emílio Kloth. Brasília: Conselho da Justiça Federal, 2008. Disponível em https:/www.unodc.org/documents/lpobrazil/Topics_corruption/Publicacoes/2008_Comentarios_aos_Principios_de_Bangalore. pdf. Acesso em: 10 abr. 2019.

. Fundo das Nações Unidas Para a Infância - Unicef. Comunicado de imprensa. 11 dez. 2018. UNICEF e CNJ se unem pelos direitos da infância e da adolescência. Disponível em https://www.unicef.org/brazil/comunicados-de-imprensa/unicef-e-cnj-seunem-pelos-direitos-da-inf\%C3\%A2ncia-e-da-adolescencia. Acesso em: 15 mai. 2019.

Judiciário brasileiro cria laboratório de inovação para promover metas da ONU. Notícia de 13 mai. 2019. Disponível em https://nacoesunidas.org/judiciario-brasileirocria-laboratorio-de-inovacao-para-promover-metas-da-onu/. Acesso em: 15 ago. 2019. 
POISOT, Eduardo Ferrer Mac-Gregor. Voto arrazoado na Resolução de 20 de março de 2013 da Corte Interamericana de Direitos Humanos, caso Gelman vs. Uruguai, supervisão de cumprimento de sentença, parágrafo 43 e seguintes.

- Voto proferido em relação à sentença prolatada pela Corte Interamericana de Direitos Humanos no Caso Cabrera García e Montiel Flores vs. México, de 26 de novembro de 2010 . Disponível em http://www.corteidh.or.cr/CF/jurisprudencia2/ficha_tecnica.cfm?nId_Ficha=343. Acesso em: 15 mai. 2019.

ROCHA, Cármen Lúcia. Voto no julgamento do AR 1.244-EI, pelo Plenário do Supremo Tribunal Federal em 22 set. 2016. Disponível no DJE de 30 mar. 2017.

TRINDADE, Cançado Trindade. Voto fundamentado no caso da Prisão de Miguel Castro Castro Vs. Perú, submetido ao julgamento da Corte Interamericana de Direitos Humanos, sentença de 25 de novembro de 2006 (Fundo, reparações e custas), série C, n. ${ }^{\circ}$ 160, trata da relação entre tempo e direito. Disponível em http://www.corteidh.or.cr/docs/casos/articulos/seriec_160_esp.pdf. Acesso em: 20 jul. 2019.

- Voto fundamentado em separado proferido no julgamento do caso Damião Ximenes Lopez vs. Brasil (sentença de 4 jul. 2006). Corte Interamericana de Direitos Humanos. Série $\quad$ C, n. ${ }^{\circ} \quad 149$. Disponível em http://www.corteidh.or.cr/docs/casos/articulos/seriec_149_por.pdf. Acesso em: 22 fev. 2019.

VATICANO. Carta Encíclica "Laudato Si"” sobre o cuidado da casa comum. Sua $\begin{array}{lllll}\text { Santidade } & \text { o } & \text { Papa } & \text { Francisco. } & \text { Disponível }\end{array}$ http://w2.vatican.va/content/francesco/pt/encyclicals/documents/papafrancesco_20150524_enciclica-laudato-si.html. Acesso em: 08 mar. 2018. 